NBER WORKING PAPER SERIES

\title{
CHANGE AND PERSISTENCE IN THE AGE OF MODERNIZATION:
}

SAINT-GERMAIN-D'ANXURE 1730-1895

\author{
Guillaume Blanc \\ Romain Wacziarg \\ Working Paper 25490 \\ http://www.nber.org/papers/w25490
NATIONAL BUREAU OF ECONOMIC RESEARCH
1050 Massachusetts Avenue
Cambridge, MA 02138
January 2019

Blanc: Brown University, Robinson Hall, 64 Waterman Street, Providence RI 02912, gblanc@brown.edu; Wacziarg: UCLA Anderson School of Management, 110 Westwood Plaza, Los Angeles CA 90095, wacziarg@ucla.edu. We thank Ran Abramitzky, David de la Croix, Paul David, Klaus Desmet, Oded Galor, Saumitra Jha, David Le Bris, Chris Meissner, Ricardo PerezTruglia, Nico Voigtlaender, David Weil and seminar participants at Brown University, UCLA, Stanford University, UC Davis and Universite Catholique de Louvain for useful comments. Funding from the UCLA Faculty Senate is gratefully acknowledged. Any remaining errors are ours. The views expressed herein are those of the authors and do not necessarily reflect the views of the National Bureau of Economic Research.

NBER working papers are circulated for discussion and comment purposes. They have not been peer-reviewed or been subject to the review by the NBER Board of Directors that accompanies official NBER publications.

(C) 2019 by Guillaume Blanc and Romain Wacziarg. All rights reserved. Short sections of text, not to exceed two paragraphs, may be quoted without explicit permission provided that full credit, including $\odot$ notice, is given to the source. 
Change and Persistence in the Age of Modernization: Saint-Germain-d'Anxure 1730-1895

Guillaume Blanc and Romain Wacziarg

NBER Working Paper No. 25490

January 2019

JEL No. N13,N33,N43,O43,O52,Z10

\begin{abstract}
$\underline{\text { ABSTRACT }}$
Using a unique, comprehensive household-level dataset for a single French village from 1730 to 1895, we study the process of modernization during a period of rapid institutional and demographic transformation. We document changes in fertility, mortality, human capital and intergenerational mobility, looking for structural breaks associated with the French Revolution and paying close attention to the sequencing of changes associated with various aspects of modernization in the village. We find that the fall in fertility preceded the rise in education by several decades. Demographic change is plausibly associated with institutional and cultural change rather than with changes in the opportunity cost of children. The rise in education occurred mostly as the result of an increase in the supply of schooling due to the Guizot Law, rather than demand side forces. All these changes occurred in the absence of industrialization in and around the village. We conclude that institutional and cultural changes originating outside the village were likely the dominant forces explaining its modernization.
\end{abstract}

\author{
Guillaume Blanc \\ Brown University \\ Robinson Hall \\ 64 Waterman Street \\ Providence, RI 02912 \\ gblanc@brown.edu \\ Romain Wacziarg \\ Anderson School of Management at UCLA \\ C-510 Entrepreneurs Hall \\ 110 Westwood Plaza \\ Los Angeles, CA 90095-1481 \\ and NBER \\ rwacziarg@gmail.com
}

A data appendix is available at http://www.nber.org/data-appendix/w25490 


\section{Introduction}

The 18th and 19th centuries were times of economic, political and social modernization in Europe. Starting from persistent stagnation in living standards over the previous millennia, this era was characterized by unprecedented waves of change: the demographic transition, defined by lasting reductions in fertility and mortality rates; the rapid accumulation of physical and human capital; the evolution, in fits and starts, away from absolutist monarchy toward more democratic modes of government; sustained technological innovation and structural change from agriculture, toward industry, and later to services; and a sustained take-off in living standards interrelated with all these trends.

These transformations characterize the typical pattern of socioeconomic development. Yet the timing of these various waves and the complex causal mechanisms that link them remain elusive. In part, this is because of lack of good data regarding transformations that occurred two hundred years ago or more. Data comparable in quality to that used today to study developing countries does not typically exist for 18th and 19th century European societies known to have made the successful transition to modernity, hampering our understanding of the links between demographic, economic and institutional change among early modernizers. In sum, we can more easily study the process of development in societies that are still making the transition to modernity than in those that long ago completed this transition. Doing this, however, is essential to fully understand the anatomy of modernization.

In this paper, we use a unique dataset for a single French village over the 1730-1895 period to make progress in this respect. This dataset, at the individual and household levels, allows us to study the process of change precisely during the time of France's transition to economic, social and political modernity. The time period under study was crucial in French development. It included demographic change, political upheaval, growing literacy, and improving living standards. We study how these and other changes are linked to each other, and how village life evolved over this period of profound transformation. We pay particular attention to issues of change and persistence. We show for instance that despite growing literacy and changing demographic outcomes, there was considerable intergenerational persistence in literacy status, social status and occupations. We also study the timing of change to better understand the forces that underlie economic, social and institutional change in France. For instance did the rise in literacy precede or follow the decline in fertility? Did the French Revolution constitute a structural break in terms of economic and demographic indicators? What role did economic incentives play in the decline in fertility and the rise of literacy? In sum, our goal is to provide a quantitative anatomy of modernization in a village representative of the broader forces affecting French society in a period of rapid transformation.

We study Saint-Germain-d'Anxure, a small rural village in the Mayenne département of Western France. We obtained detailed data at the individual and household level from civil records, censuses and tax rolls for this village over a period of 165 years. We digitized nearly 7,000 handwritten birth, death and marriage records - the universe of all births, deaths and marriages occurring in the village 
over this period. The data contain a wealth of information on intergenerational links, literacy status, profession, social networks, and allow a precise reconstruction of the demographics of the village over the crucial decades that straddle the French Revolution. A unique feature of the dataset is that we can explicitly link individuals across generations. This allows for a detailed analysis of social mobility and intergenerational persistence of various socioeconomic features, such as literacy, social classes, and occupations. These data were supplemented by periodic archival information from censuses, tax rolls, and qualitative sources. While our study concerns a single village, we argue that this village was typical of a rural French life in the 18th and 19th century. We hope, at any rate, that we gain more in terms of detail, granularity and specificity than what we might forego in terms of generality.

Saint-Germain-d'Anxure (henceforth, SGA) is located near the geographic center of the Mayenne département, midway between the region's two major towns, Laval and Mayenne (Figure A1.0.0.1 historical map of Mayenne). SGA had between 500 and 600 inhabitants at any point in time over the period under study (the population in 2013 was 372). Major economic activities included agriculture (wheat and barley, chestnuts, some animal husbandry) and textile weaving. The village traces its origins back to the Saxon invasions in the $7^{\text {th }}$ Century. Through the centuries that followed the crusades, a single family, the Montgiroux, exercised lordship over much of the village and surrounding lands. In 1656 the Castle of Montgiroux and surrounding lands were sold to the Cardinal de Mazarin, and in 1790 these landholdings were divided and sold to several landowners (Figure A1.0.0.2 presents a map of the SGA municipality as of 1835, and Figure A1.0.0.3 shows historical and contemporary photos of the main village). SGA was largely spared from the violence that surrounded the French Revolution, and the royalist counterrevolution that engulfed nearby locations (the Chouannerie) did not directly operate in the village. A full-time schoolteacher paid by the municipality and prefecture was appointed in 1834, a school for boys was built in the village in 1841, following the Guizot Law that boosted boys' primary schooling across France. A school for girls opened in 1859!1 In every respect, then, SGA was an ordinary village buffeted by the various historical forces that shaped the modernization of France at the end of the 18th Century and throughout the 19th Century.

Over the period under study, SGA displays both change and persistence. Modernization took the form of profound change in demographics and human capital. Over the period 1730-1750, literacy rates for males and females averaged, respectively, $11 \%$ and $5 \%$. At the end of the sample period, over 1875-1895, literacy for both sexes averaged about 85\%. Fertility rates both gross and net declined steeply, by over 50\%, when comparing the periods 1740-1760 and 1860-1880. Child mortality (the probability of dying before one's fifth birthday) declined from $26 \%$ (1740-1760) to $15 \%$ (1870-1890), while life expectancy at age 20 climbed from 43 to 62 years between the first and last twenty years of our sample period. The end of feudalism and the slow transition to democracy that occurred over the span of the 19th century were associated with a broader distribution of landholdings: in our database of village households, over 1760-1780, 1\% of households are recorded as owning some land, while over

\footnotetext{
${ }^{1}$ The information in this paragraph is sourced from Marcadé (1899).
} 
1875-1895 that proportion rises to $7 \%$. Over the period, we witness the transition from feudalism to local democracy, as local lords who previously had dominion over the village sold land to a broader array of landholders, and local municipal institutions supplanted church and nobility as the drivers of local public goods allocation. Finally occupational and social class mobility increased over the 165 years that span our study: the proportion of children who were in the same social class as their fathers fell from $84 \%$ in the $1780-1800$ period to $67 \%$ in the $1875-1895$ period. At the same time, the village was left untouched by industrialization. The share of the adult male population engaged in agriculture remained stable, at $67 \%$ in $1780-1800$ and $69 \%$ in $1875-1895$. SGA's small textile weaving industry declined from $11 \%$ to $5 \%$ of the adult male population during the same period.

Thus, in this village, modernization proceeded without industrialization. As we argue below, demographic behaviors, human capital accumulation and social relationships changed as the probable result of a complex mix of cultural change and institutional upheavals triggered by the Age of Enlightenment and the French Revolution. Absent from the main drivers of demographic trends, however, were any dramatic changes in the returns to human capital and to the structure of the local economy. In fact, the timing of the changes observed at the level of the village suggests that fertility and mortality fell first. This is followed by the rise of human capital as a result of educational mandates that proceeded from institutional change (in particular, the Guizot Law of 1833 subsidizing the provision of primary education). The increase in social mobility then followed. In this context, the decline of fertility is unlikely to be the result of changes in the individual or household level trade-off between the quantity and quality of children, and is more likely the primary result of changes in cultural attitudes, as well as the decline in child mortality. The accumulation of human capital is also unlikely to be the result of individual decisions stemming from industrialization, as France overall experienced late industrialization and urbanization. The rise in literacy is more plausibly the result of institutional change, working largely by raising the supply of educational services at the village level. We see little evidence of structural change away from agriculture during our sample period. In sum, the modernization of demographic behaviors and the accumulation of human capital occur without the backdrop of industrialization, but appear to be mostly influenced by cultural and institutional upheavals associated with the Age of Enlightenment, the French Revolution and their aftermath.

Our paper is related to a vast literature in demography, history and economics analyzing the advent of modernity in France at the local level. We are not the first to focus on detailed data from a single village. For instance, Gauthier and Henry (1958) focus on demographic change in a single village of Normandy in the 17th and 18th centuries, Ganiage (1963) does the same for three villages in the suburbs of Paris in the 18th century, and Weir (1995) examines the demographics of RosnySous-Bois in the mid-18th century. Hadeishi (2003) studies the village of Nuits, in Burgundy, between 1744 and 1779, finding an early decline of fertility and a positive correlation between fertility and income. These contributions (and many others too numerous to cite here) focus almost exclusively on demographic change, whereas we attempt a more comprehensive account of modernization among many other dimensions: not just demographics but also human capital, local institutions, and social 
mobility $\left.\right|^{2}$

Our work also relates to a more qualitative literature in the discipline of history. Probably the most famous is LeRoy Ladurie (1975), a detailed study of a village of Southern France from 1294 to 1324 (thus very far removed from our time period). In contrast to this type of narrative study we adopt an explicitly quantitative approach. Another major contribution is Eugen Weber's book on the modernization of rural France between 1870 and 1914 (Weber, 1976). We deal with a somewhat earlier period. Dealing with a more recent period of French modernization, economic historian Jean Fourastié authored a famous study of the 30 years of economic growth that followed the Second World War, opening with a striking narrative describing the transformation of a single village, Douelle in southwestern France, between 1946 and 1975 (Fourastié, 1979). We too document changes taking place in a single village, but at an earlier time.

Finally, our research contributes to a more quantitative literature on French demographic change and modernization. References here are again too numerous to mention comprehensively, so we mention but a few: Louis Henry's comprehensive and path breaking project using parish records to track of the evolution of French demographics prior to 1800 (Henry, 1972a, 1972b, 1978; Henry and Houdaille, 1973; Houdaille, 1976; Séguy, 2001); Wrigley's (1985) study of the fall of marital fertility in 19th century France; Coale and Watkins' (1986) study of the decline of Fertility in Europe (in particular the extensive material concerning the case of France that this book contains); and more recently Cummins' (2013) study of marital fertility in four villages of rural France between 1750 and 1850.

This paper is organized as follows: Section 2 discusses theoretical considerations and further background information on the history and geography of SGA. Section 3 briefly describes the extensive data-gathering effort that underlies this study (details are relegated to Appendix 1, the data appendix). Section 4 examines change and persistence in demographic characteristics over the study period. Section 5 turns to the evolution of literacy and human capital. Section 6 discusses the structural transformation and social mobility. Section 7 brings these findings together to discuss the sequencing of modernization in the village. Finally, Section 8 concludes.

\section{Conceptual Considerations and Historical Background}

\subsection{Conceptual Considerations}

Understanding the factors that led to sustained increases in per capita income has occupied economists since the inception of the discipline. It is not our purpose here to summarize these factors comprehensively, but instead to discuss briefly major hypotheses explaining differences in prosperity in order

\footnotetext{
${ }^{2}$ Smith (1975) studies work habits and social structure in 19th Century Cruzy, a village of Southern France, but once again does not adopt the more comprehensive approach that we pursue. In a more contemporary context, the Palanpur project comprehensively follows the modernization of a single village in Uttar Pradesh, India, since 1957 (Lanjouw and Stern, 1998).
} 
to organize our analysis of the process of modernization in SGA.

Major accounts of the transition from stagnation to modernity stress different underlying factors. The most ambitious and comprehensive of these accounts in Unified Growth Theory (henceforth UGT: Galor and Weil, 2000, Galor, 2011). This theory provides an integrated articulation of the links between technological progress, human capital accumulation and the demographic transition in order to account for the growth take-off. It is difficult to provide a concise summary of UGT that does justice to its intricacies, but a succinct account would be as follows: societies in Malthusian regimes will escape stagnation when technological improvements becomes sufficiently pronounced to counteract the endogenous positive response of population growth to technological progress. In the post-Malthusian regime, technological progress raises the demand for human capital (and also incentives to supply educational services). The more pronounced incentives to accumulate human capital modify the trade-off between the quantity and quality of children, triggering a reduction in fertility and thus a demographic transition. In the modern regime, per capita income can rise in a sustained way because technological progress is no longer counteracted by population growth. In a nutshell, the primitive force leading to modernization is technological progress, which itself can be endogenized with respect to some deep geographic, historical and cultural factors (Galor, 2011, Spolaore and Wacziarg, 2013).

Other accounts of the growth take-off emphasize a different mix of triggers and mechanisms. For instance, in Mokyr's historical accounts of the growth take-off, technological progress (knowledge) is at the center of the take-off, and the role of knowledge elites is paramount ${ }^{3} \mathrm{~A}$ virtuous reinforcement of prosperity brought about by technological progress driven by knowledge elites came from cultural and institutional improvements that protected the fruits of this progress from predatory rent-seeking and redistribution (for instance a general improvement in property rights protection, and the emergence of a culture that valued progress and science). Demographic change and generalized human capital accumulation only came later, at least in the case of England, as by-products of what Mokyr calls "the Industrial Enlightenment".

Yet other accounts place institutional change at the center of the process of modernization (North and Weingast, 1989; Greif, 1993, 2006; Acemoglu, Johnson and Robinson, 2001; Acemoglu, Cantoni, Johnson and Robinson, 2011, among many others), arguing that institutions are the prime cause of variation in the wealth of nations and that institutional change was a major trigger for the growth

\footnotetext{
${ }^{3}$ Thus Mokyr (2000, p. 254) states: "The key to the Industrial Revolution was technology, and technology is knowledge". See also Mokyr (2005, p. 47): "The argument I propose, that technological progress is driven by a relatively small number of pivotal people, is not a call for a return to the long-defunct "heroic inventor" interpretation of the Industrial Revolution. The great British inventors stood on the shoulders of those who provided them with the wherewithal of tools and workmanship. (...) Below the great engineers came a much larger contingent of skilled artisans and mechanics, upon whose dexterity and adroitness the top inventors and thus Britain's technological success relied. These were the craftsmen, highly skilled clock- and instrument-makers, woodworkers, toymakers, glasscutters, and similar specialists, who could accurately produce the parts, using the correct dimensions and materials, who could read blueprints and compute velocities, understood tolerance, resistance, friction, and the interdependence of mechanical parts." Squicciarini and Voigtländer $(2015,2016)$ provide strong empirical evidence for a growth take-off spurred by knowledge elites.
} 
take-off associated with the Industrial Revolution.

Finally, some accounts give demographic factors more prominence. The trigger for such demographic change varies across accounts, but the demographic transition characterized by reductions in fertility rates is central to the process of economic and social modernization (Becker, Murphy and Tamura, 1990, Galor and Weil, 2000). Whether the trigger of such demographic change was a reduction in mortality, technological progress leading to a different choice on the trade-off between the quality and quantity of children, or other causes, the transition from a regime of high fertility and high mortality to one of low fertility and low mortality is a central element of the transition from Malthusian times to modern growth. $4^{4}$

Most accounts of the socioeconomic modernization that occurred in the 18th and 19th centuries consist of articulating causal relationships between four major factors, emphasizing their roles with different degrees of salience. These four factors are: technological progress and the resulting structural transformation; the accumulation of human capital; the demographic transition; and institutional change. We use these four categories as a roadmap: our account of the anatomy of modernization in SGA will seek to shed light on the evolution of these four factors in the village over 1730-1895, and to articulate their likely interrelationships. Our setting allows us to look at these changes at the household level rather than in aggregate; it allows us to precisely characterize the sequencing of the various changes; and it allows us to use intergenerational information to examine mobility in socioeconomic status and literacy. In sum, it allows us to provide a precise account of the interactions between the four major factors underlying the process of socioeconomic modernization.

\subsection{Background on Saint-Germain-d'Anxure}

We begin our anatomy of SGA's modernization by providing some general background information on the village, its structure, history, major features, and representativeness of other French villages in the period under study 5 Table A2.2.0.1 shows the population of the village fluctuated between 500 and 630 inhabitants between 1793 and 18916 Putting this in the French context, in $183685 \%$ of the

\footnotetext{
${ }^{4}$ Doepke (2010) provides a useful typology of the triggers of the demographic transition and subsequent growth take-offs: "In Galor and Weil (2000), the takeoff is ultimately a consequence of technological progress. Accelerating productivity growth increases the return to education (...), which eventually triggers the quantity-quality substitution and the growth takeoff. (...) Yet other authors have emphasized the role of declining mortality rates (...), increasing female labor-force participation (...), changes in the provision of old-age security (...), changes in child-labor and education laws (...), and the introduction skill-intensive production technologies that raise the return to education (...).

${ }^{5}$ The discussion below draws in particular on the Communal Monography of 1899, written by the village schoolteacher E. Marcadé in preparation for the 1900 Paris World Fair (Marcadé, 1899).

${ }^{6}$ Until 1850 population trends in SGA and in France overall are quite similar. Around 1850 SGA's population starts to decline while the population of France continues to grow. As we discuss below, this coincides with the beginning of net outmigration from the village to larger towns, and may account for the differential population trends between SGA and the rest of France. Comparing the population of SGA to that of rural France (defined as people living in towns of less than 5,000 inhabitants), we find almost identical evolutions, with population growing by about $20 \%$ from 1800 to
} 
French population lived in towns with fewer than 5,000 inhabitants, $79 \%$ in towns with fewer than 3,000 (Statistiques Générales de la France, 2011a). This is in contrast to England, which was much more highly urbanized in the early 19th century (Bairoch and Goertz, 1986).

SGA was relatively isolated, located in the center of a landlocked département, and connected to other villages merely with dirt paths 7 Two major rivers delineated the Northeastern and Southeastern borders of the municipality: respectively the Anxure and the Mayenne, only the second of which was navigable. The 19th century saw some improvements in infrastructure (a bridge over the Mayenne river, a road built for military purposes connecting the village to the nearby town of Mayenne, both built in the early 1830s). A rail line linking Paris to Brest, stopping in Laval, started operating in 1855 (Laval is currently 21 kilometers from SGA by the shortest road).

As mentioned already the economy was based mostly on agriculture (oat, wheat and barley were the major crops). In this way, the village is representative of the rest of France. Indeed, in 1788, 68\% of the working population in France was in the agricultural sector, and this share was still $48 \%$ in both 1864 and 1894, at the end of our sample (Morrisson and Snyder 2000, Table 12). In France in general, in the pre-Revolutionary period agricultural holdings took several forms: closeries were small-scale landholdings leased to farmers (closiers) through sharecropping arrangements. Métaieries were larger landholdings usually owned by nobility, also operated by farmers (métayers) under a mix of monetary contracts and sharecropping arrangements. The structure of landholdings changed in the second half of the 18th century and then after the French Revolution, with agrarian reforms leading to enclosures and gradually limiting the use of land by those without property rights, known in France as vaine pâture, or common pasture (Rozental, 1956). Contracts increasingly took the form of leases instead of sharecropping arrangements. After the Revolution, the feudal rights of the nobility were abolished and many métaieries were sold for the benefit of the state 8 This, combined with the abolition of the right of primogeniture in 1789, led to smaller farms. These general trends for France applied with some qualifications to both the Mayenne region and SGA: the impact on the Mayenne region was limited as that region already had relatively small farms and enclosures prior to the reform period,

1850 and declining by about $10 \%$ from then to 1890. After 1850 all population growth in France occurs in urban areas, while rural population declines. These statements are based on data from BDCassini (2017).

${ }^{7}$ In this respect also, the village was quite typical of France. Analyzing data on road length per capita in 1793 from the Cassini database (Perret et al., 2015), we found that SGA featured 3.3 meters of road per capita (in a 20 kilometer radius from the village boundaries) while the corresponding figure for France overall was 4.1 (including urban areas). SGA's road density is well within one standard deviation of the French mean.

${ }^{8}$ Morrisson and Snyder (2000) observe: "The abolishment of the feudal rights of nobles also enhanced the income of the lower class of farmers who no longer were subject to work corvees and other obligations to their seigneurs. Perhaps the most important aspect was the confiscation of church properties and those of many nobles. These were auctioned as biens nationaux. While the largest group of buyers were the larger farmers and bourgeois who already possessed land and had the means to acquire more, there were many from the lower ranks of the agricultural hierarchy who were also able to acquire some of the lands auctioned by the government. As a consequence, the structure within the agricultural sector changed dramatically." 
and was therefore not primarily targeted by these reforms.9 However, consistent with the national trends, we do see some fractionalization of landholdings in SGA during our sample period, as a result of the declining power of the nobility (as already mentioned in Section 1; see also our discussion in Section 6). The use of day labor (domestiques or journaliers) on farms was ubiquitous, and these workers represent one of the largest occupational groups in our sample.

Technological progress came late to the agricultural sector in this region. Agricultural lime and manure were the main soil amendments, as phosphate-based fertilizers only came into use after 1880. Major technological innovations, including the generalized use of the Brabant plough and even of steam-powered combine harvester on about 10 of the largest farms, did not occur until the end of the 19th century, at the end of our sample period (Marcadé, 1899).

Besides agriculture, there was a small textile sector in the village throughout the 18th and early 19th centuries. Cotton progressively replaced linen as the main textile product over this period. In this industry, small-scale weavers and tailors were the norm, with very limited use of mechanization. In the later part of the 19th century the textile industry declined in the village, as the probable consequence of competition from the opening of a textile mill in the nearby town of Andouillé. There was also a stone quarry within the municipality, and a variety of artisans working in the village. As can be seen, therefore, there was no modern industry to speak of in SGA - even the declining textile activity was based on traditional technology. This is in the broader context of the very late industrialization of France, compared to England: not only was SGA relatively isolated from the rest of France until well into the 19th century, France itself was not subject to significant industrialization until the second half of the 19th century (Levy-Leboyer and Bourguignon, 1985). This is well after the changes in fertility and literacy that we document for SGA, suggesting that these early changes cannot be easily attributable to industrialization outside of SGA. We return to these important observations in Section 6.

Turning to local institutions, in the pre-Revolutionary period the village was under the authority of the Duchy of Mayenne, controlled by the Cardinal de Mazarin. During the French Revolution, there was a brief period of broad-based suffrage for the election of mayors, which was abolished in 1799 . There were no municipal elections during the Bourbon Restoration (1814-1830), as the mayor was appointed by the prefect. During the July Monarchy (1830-1848), the mayor was still appointed, but had to be chosen from among a set of $6-13$ municipal councillors, who were elected within the village. Franchise eligibility was based on tax payments above a certain threshold, but in villages of less than a thousand inhabitants, where too few potential voters met this criterion, there was a requirement that $10 \%$ of the total population be allowed to vote in municipal elections. Hence, in SGA about 60 male inhabitants were eligible to vote (only 6 of those met the tax criterion for franchise eligibility in 1838). Universal male suffrage became the rule after 1848.

\footnotetext{
${ }^{9}$ According to Rozental (1956), "In the West and in the Central Provinces, enclosed smallholdings predominated. The pasture and the meadow remained open to all, but the arable was enclosed by hedges."
} 
We end this brief background discussion with some observations on surnames and first names. As noted by Marcadé (1899), "it is not uninteresting to note that the main families of the municipality have perpetuated themselves for several centuries. The baptism registries prior to 1789 reproduce approximately the same surnames as those in this day [1899]. The Municipal Council of 1789 displays almost the same names as today's municipal council. We can conclude that families maintain a deep attachment to their place of origin and that through order, thrift and the dignity of their existence, they learned to maintain their reputation through the years". We were able to verify the truth of this statement by examining the persistence of surnames in the various records used to form our database. Table A2.2.0.2 displays the 15 most frequent surnames found in these records prior to the French Revolution. Figure A2.2.0.1 shows the high persistence of these 15 surnames: $34 \%$ of spouses in SGA households bear one of these surnames before 1789. This proportion then gradually falls, perhaps as a result of migration through marriage and other forms of migration, to reach about $20 \%$ in 1840 and $14 \%$ in 1880. There is also persistence in first names (Table A2.2.0.3 and Figures A2.2.0.2): prior to the Revolution almost $40 \%$ of children are given the same first name as one of their parents. This share declines to about $22 \%$ in 1860 , despite the fall in fertility. Similarly, before 1789 about $80 \%$ of children (girls and boys together) were given a first name in the top 15 of given names, and this percentage fell between 1825 and 1870, to below 45\%. Especially common were the widespread French names Jean, Pierre, Michel, François (for boys) and Jeanne, Françoise, Anne and Marie (for girls). Reading through the parish and civil records of births, deaths and marriages, one sees a steady presence of these main names throughout the 18th century, gradually giving way to less common names in the second half of the 19th century - an interesting manifestation of modernization.

\section{The Data}

We assembled a comprehensive database on the village from a multiplicity of sources. The main data consist of parish and civil records at the individual level, from 1730 to 1895. This database was supplemented with data from tax rolls, municipal budgets, censuses and qualitative sources.

\subsection{Construction of the Database}

We systematically tracked all individuals across their lives using birth, marriage and death records. In doing so, we were able to gather a vast amount of information on literacy, occupations, demographic behaviors, mortality and, last but not least, inter-generational linkages.

\subsubsection{Records and Raw Data: The Acts Database}

Over the past few years, French prefectures made available scans of handwritten parish and civil records going back as early as the 16th century 10 After 1793, as a result of the French Revolution

\footnotetext{
${ }^{10}$ These are the same records that Fleury and Henry (1956) used for their study of Ancien Regime populations. The records that form the basis of our database are available at http://www.lamayenne.fr/fr/Archives53/Archives-en-
} 
and its concurrent process of secularization, the task of maintaining civil records was transferred from the Church to municipal authorities, although the format of the records was little changed. Archives include birth, death and marriage (BDM) records 11 We painstakingly digitized 165 years worth of all available village records, for the period 1730 to 1795, dealing with sometimes hard to decipher handwriting (Figure A3.1.1.1 being an example of poor handwriting). In total, we digitized 6,797 records, including 3,315 births or baptisms, 2, 566 deaths and 919 marriages.

From these records we were usually able to obtain the names and occupations of the parents and witnesses. Using ability to sign one's own name on the record as an indicator of literacy, we could also characterize signatories' literacy status ${ }^{12}$ As an example, Figure A3.1.1.2 is a baptism record from February 24th, 1780. The information in brackets was coded, and includes the child's date of birth (he was born and baptized on the same day), his parents' occupations and literacy, and the same set of information for both witnesses and godparents. We also noted the name of the person who recorded the act.

Figure A3.1.1.3 displays the evolution of the annual number of records across time. Figures A3.1.1.4 to A3.1.1.6 highlight how often we were able to identify individual characteristics depending on the type of records (also summarized in Table A3.1.1.1) and the period. We were able to characterize literacy status for almost all men across time using birth and marriage records, while for women marriage records are the only comprehensive source for literacy. Occupations were systematically recorded in the acts after 1780 for men and after 1840 for women (in both birth records, for parents of the newborn, and in marriage records, for those getting married). One challenge was correctly identifying the date of birth for individuals mentioned in marriage and death records. Marriage and death records usually provide ages (often rounded to the nearest decade), but not precise birth dates. This created challenges to correctly match birth, marriage and death records to single individuals, in order to reconstruct their biographies, as discussed further in Section 3.1.2.

Illegitimate births represent about $1.6 \%$ of the total number of recorded births. In the prerevolutionary period, these were often recorded in Latin : illegitimo concubito or pater incognitus being the most common occurrence. We also noted 8 marriages between cousins of the 3 rd or 4 th degree (only recorded before 1793). In these cases the bride and groom had to request permission to marry from the Bishop of Le Mans.

Each observation in the Acts Database is a record (with one observation per person getting married for marriage records). We used a common nomenclature of last names and first names so as to limit bias stemming from name changes or spelling variants. Name changes can result from official acts

ligne/Etat-civil. Records exist going back to 1629, but contain far less information, are harder to decipher, and records pertaining to $1715-1729$ are mostly missing, so we start in 1730.

${ }^{11}$ The Church would register both birth and baptism dates, while municipal authorities recorded birth dates only.

${ }^{12}$ Using the ability to sign to determine literacy status is common practice in the literature. See for instance Allen (2003) and Clark (2014), among many others. 
(Figure A3.1.1.7 is an example of an order issued by the court of Mayenne to legally change the last name of an individual). Spelling variants are more common. For example Alix, one of the most common surnames in our database, is sometimes spelt Alie, Alis, Elis or Elie depending on who does the recording or depending on the period. The Acts Database provided the baseline information for constructing other datasets, to which we now turn.

\subsubsection{The Households Database}

From the acts database, we created a database at the household level, for three reasons: first, we are interested in analyzing behavior, such as fertility, where decisions are made at the household level; second, it allows us to check information across different records in order to limit errors and missing values; third, it helps us address the question of migration, which is addressed in detail in Section 3.3. Migration is mostly to and from nearby locations: $50 \%$ of SGA newlyweds were born in SGA but $98.9 \%$ were born in the département of Mayenne.

We began by identifying parents either from the births or baptisms records, since they are always recorded there (we dropped the uncommon cases where births are from unknown fathers). Each parent pair constitutes a single observation in the households database. We coded information such as the couple's number of children, the parents' occupation and literacy. We matched these couples to any available marriage records, allowing us to note the place of birth and sometimes the age of the members of the couple, but also and most importantly information on the preceding generation (occupation and literacy). These matches are a rich source of intergenerational information. In addition, we added couples identified through marriage records only, i.e., couples who did not subsequently have recorded births in SGA later in time. The households database hence includes all couples with at least one child born in SGA, and all marriages ${ }^{13}$ It contains 1,650 households. Finally, in this database, the year of household formation was coded as of the year of marriage (if available) or the year of birth of the first child. Appendix 1.1 provides more details on the construction of the households database.

A unique feature of our dataset is the ability to link generations. We link mothers and fathers to both sons and daughters, but in our main analysis we mostly use father to son linkages. Out of the 900 marriage acts we observe, 699 identify the father of the groom. Additionally, we use the birth records of individuals for whom we do not have marriage records to link further observations: birth records usually provide information on the father of the child, allowing us to trace intergenerational linkages for the corresponding individuals. We painstakingly went back in time, decade by decade, starting two decades prior to the birth of the first child, to find the father's birth record. The repeated use of a small set of first names sometimes makes it hard to clearly identify individuals of given lineages but this procedure allowed to provide intergenerational linkage for an additional 263 individuals. Of the

\footnotetext{
${ }^{13} \mathrm{~A}$ remarriage corresponds to the formation of a new household. Fertility is therefore calculated as household fertility, so-defined. Among all marriage acts, $9 \%$ of men and $5 \%$ of women are characterized as remarrying. There is almost no time variation in the remarriage rate.
} 
resulting 962 intergenerationally linked father and son pairs, we observe literacy status across both generations for 581 pairs.

\subsubsection{The Deaths Database}

The households database covers all death records for parents that married or gave birth in SGA, as well as for children born in SGA that we were able to match to a death record within their first 5 years of life, but it does not include death records of people that were not married and did not give birth in SGA. In the death database, we start from all available death records (2,566 records) and add to these records individual-level information matched from birth and marriage records. Thus the death database contains information such as literacy, class, occupation, etc. - information that is not generally available from death records. Here the unit of observation is an individual, not a household.

\subsubsection{Categorization of Occupations, Classes, Skills and Periods}

Table 3.1.4.1 summarizes our categorization of professions into occupations and the categorization of occupations into social classes. There is a vast literature in demography and history noting the shifting definition of professions over time (Beaur, 1999). In order to reduce the resulting bias, we grouped professions into broader occupational categories (day laborers, farmers, textile worker, unskilled craftsmen, skilled craftsmen and bourgeois). For example, blacksmiths are classified as skilled craftsmen, since they were often practicing as veterinarians (Knittel 2004) 14 Except for the upper classes, data on occupations was scant before 1780, and became more plentiful thereafter (see discussion in Section 3.1.1). Thus, to limit the incidence of sample selection, when using data on occupations and classes (Section 6) we begin our sample in 1780.15

We further assigned a skill and a class score to each occupation. For skills, we compared average literacy rates per occupation to average literacy across the sample. The skill score equals the average literacy rate for a given occupation divided by the average literacy rate, using the sample of households formed before 1845 (note that, before the building of the school in 1841, only a small minority was literate, so there was scope for a lot of variation in literacy across occupations). The skill score is a measure of an occupational category's human capital intensity. Table A3.1.4.1 shows that the skill score lines up nicely with the categorization - day laborers are the least literate while skilled craftsmen and upper professions are the most literate.

For the class score, we used the father's literacy as an exogenous source of variation in class, again using the sample of households formed before 1845. We computed the probability of choosing one

\footnotetext{
${ }^{14}$ Also noted in the definition of blacksmith in Diderot and D'Alembert's Encyclopédie.

${ }^{15}$ Appendix Figure A3.1.4.1 assesses the extent of sample selection by plotting the time path of literacy for the full sample, the subsample for which class is available at any point in time, and the sample for which class can additionally be tracked over two generations. The latter two series diverge significantly from the first one prior to 1780 , but not after. There is evidence that households for which class and intergenerational information on class are available have particularly high literacy prior to 1780 , indicating that the sample is not representative before that date.
} 
occupation rather than all others, conditional on the literacy rate of the father. The class score is thus defined as an odds ratio: it equals the probability of a given occupation if the father was literate divided by the probability of the same occupation if the father was illiterate. For example, a person is 2.99 times more likely to be a skilled craftsman when his father was literate than when his father was illiterate. We display the results in Table A3.1.4.2. We used the class score to classify individuals into different social classes: upper, upper-middle, lower-middle and lower classes.

Lastly, we defined three periods using the following structural breaks: the French Revolution in 1789 and the building of a school for boys in 1841. Thus, Period I runs until 1789, Period II is defined over years 1790 to 1840, while Period III starts from 1841 and includes all subsequent years.

\subsubsection{Reporting and measurement error}

Various types of reporting biases and measurement error can occur in data of this type. First, the reporting of baptisms may be incomplete, leading to an under-registration of births. The priest recorded the baptism before 1793, and the prefecture of Mayenne is one of the most religious in France, with $62 \%$ of children still baptized in 2013 as compared with an average of $32 \%$ in France ${ }^{16}$ Baptism was almost universal, so parish records are likely to capture the vast majority of births occurring in the village. Moreover, in the household database, only $1.4 \%$ of newborns were not immediately registered after birth (defined as not being registered in the same calendar month as the birth), most often because of various reasons such as the parents marrying after the birth. This rate is stable across time, which indicates that under-reporting of births should be a limited problem.

Second, there is a well-documented issue of under-reporting of infant mortality (Henry and Blum, 1980). Usually, villages with severe under-reporting of infant and child mortality display a rate that is below 5\% (Henry, 1972; Fine-Souriac, 1978). On average, in our dataset, about 18\% of children die within their first year (before the French Revolution).

\subsection{Complementary sources}

We supplement these civil records with a number of qualitative and quantitative sources. These sources include tax rolls after 1826, from which we have data on both the contribution foncière, a tax on real estate wealth, and the contribution personnelle et mobilière, a tax on rents and industrial income. We gathered data on public revenues and expenditure, again after 1830 . We also digitized voter lists at the municipal level from 1840 to 1844 and from 1868 to 1893 . We supplemented these sources with the Agricultural Statistics of 1852 and the records of workers' logbooks starting in 1856. Last but not least, we also use a variety of sources (journal articles, books) that describe life in SGA over the sample period, from the search engine of the French National Library (Gallica) ${ }^{17}$

\footnotetext{
${ }^{16} \mathrm{http}$ // www.la-croix.com/Religion/Actualite/Baptemes-mariages-pretres-l-Eglise-de-France-en-cartes-2014-06-061190969

${ }^{17}$ http://gallica.bnf.fr/. A simple search for "Anxure" reveals interesting information and anecdotes on the village.
} 


\subsection{Migration}

In and out migration is an important concern in our data, particularly when it comes to the analysis of fertility, since migration can affect the number of recorded births for each household. Migration resulting from marriage (to either spouse's village) is likely the main source of regular migration. In the households database, $49 \%$ of observations involve one spouse born in SGA while the other was not, $24 \%$ involve both spouses born in SGA, while $27 \%$ involve neither born in the village. Of those individual spouses not born in SGA, 99\% were born in the département of Mayenne, and of these, $72 \%$ were born in municipalities contiguous to SGA. Thus, there is very little long range migration. Local migration for the purpose of marriage implies that some couples married in SGA did not remain there, while some couples not married in SGA settled there, and this was the main motive for moving in and out of the village 18 Migration to distant places to pursue greater opportunity came only later, and at least during Periods I and II such expected migration is unlikely to provide incentives to accumulate human capital or reduce fertility. Blanc (2019) further documents these observations for France overall.

Wars and other events can lead to more occasional spikes in migration. Systematic migration due to economic reasons is not likely to occur very frequently until the second half of the 19th century. The bulk of net migration out of French rural villages occurred in the first half of the 20th century. Indeed the total population of SGA is stationary over our sample period, and only starts to fall in 1896. The fall accelerates in the second decade of the 20th century.

We address the issue of migration by creating various migration scores meant to capture the likelihood that a household did not remain or originate in SGA. For each household, the migration scores capture the probability that it spent its fertile years in SGA, based on information gathered in the household database. The scores have to reflect in and out-migration while avoiding the issue of selection on the dependent variable. For instance, in fertility regressions we obviously want to avoid using a sample of households conditioning on couples having a certain number of children born in SGA. Thus, we avoid scoring explicitly on the number of children born in SGA. Appendix 1.2 describes how the migration scores were generated. The algorithm relies on information from the households database on births, marriages and deaths. To summarize, the migration scores are mostly based on whether neither member of a couple was born in SGA or whether neither member died there ${ }^{19}$ Figure A3.3.0.1

\footnotetext{
${ }^{18}$ There was no systematic rule for whether grooms came to the bride's village to marry, or vice versa. Looking among marriages where exactly one spouse was born inside the village, $42 \%$ of grooms and $58 \%$ of brides were born in SGA. So there is a small bias in favor of getting married in the bride's village of birth. There was no rule either on where a couple married in SGA would ultimately settle. Among marriages where exactly one spouse was born in SGA and this couple had at least one child in SGA, the groom was born in SGA in 54\% of the cases and the bride in $46 \%$ of the cases. So there is a small bias in favor of settling in the groom's village of birth.

${ }^{19}$ Our approach is similar to that in de la Croix, Schneider and Weisdorf (2018, Section 5). These authors create a migration indicator for households in pre-Industrial English parishes, representing their status as in-migrants, outmigrants or stayers, based on life events such as being born, married or deceased in a given parish. They do so in order
} 
plots the sensitivity of the fertility series to alternative migration score definitions. The dynamics of fertility for the period 1765-1835 do not depend on the specific version of the migration score.

We use our baseline migration score (score B) in the bulk of our empirical analysis, where we use only households with a migration score greater than 50\%. Furthermore, among the remaining observations, we linearly down-weigh households more likely to have migrated. Whenever we use the intergenerational sample, where outcomes are linked across generations (literacy, socioeconomic status), i.e. in Sections 5 and 6, we are careful to assess the representativeness of the sample. In this sample, by definition migration is less likely to have occurred than in the full sample, since two generations of village dwellers have to be observed. We compare the time paths of the series of interest in the intergenerational and full samples, finding in all cases that they overlap almost perfectly.

\section{Change and Persistence in Demographics}

\subsection{Fertility}

\subsubsection{Descriptive Trends}

Our first step in the account of the transition to modernity in SGA starts with demographic change. As noted in Section 2, the demographic transition plays an extensive role in the process of modernization. The transition from Malthusian to modern growth is characterized first and foremost by a decline in fertility. In this subsection, we analyze trends in fertility rates in the village over the period 1740-1885.

We start by describing how the fertility data was constructed from the underlying civil records. Further details are in the data appendix, but for now we note the following: We start from the households database: 1,650 couples who were either married in SGA or had any number of children born there. We condition on couples with migration scores above $50 \%$ (1,019 couples remained) and linearly weigh observations by migration score ${ }^{20}$ We compute average fertility over periods I, II and III. For a more continuous measure, we also constructed 20-year overlapping windows centered on each year, and calculated the average fertility of couples whose first child was born during each window.

SGA was quite typical of the early decline in fertility that occurred throughout Northern France (Coale and Watkins, 1986): Figure 4.1.1.1 and Table 4.1.1.1 show that fertility declined from an average of 3.29 children per couple in the $1740-1789$ period to 2.42 in the $1790-1840$ period and to 2.18 from 1841 to 1885 . Given our procedure to account for migration, it is important not to give too much weight to the absolute level of fertility during any of these three periods, which likely to be downward biased, and rather focus on changes across periods. The timing of the fertility decline is

to see if selective migration affects their findings on the evolution of fertility rates across different social classes. They find that this is not the case.

\footnotetext{
${ }^{20}$ We use score $B$ (see Appendix 3) as it allows to use migration score outside of the $1765-1835$ window. We further remove the first and 10 last years of the sample period, in order to better track total births per household. 894 households remained.
} 
earlier than that reported in Coale and Watkins (1986) for Mayenne: they date the marital fertility transition (defined as a $10 \%$ decline in their measure of marital fertility) as 1845 , whereas the bulk of the transition displayed in Figure 4.1.1.1 occurs between 1789 and 1810. This is largely due to the fact that the Coale and Watkins sample starts in 1831, so that they may miss the early part of the transition. Moreover, we record the fertility level of a couple as of the year or marriage or the year of birth of their first child, causing our timing of the decline to be possibly anticipated by three or four years at most 21

\subsubsection{Explanations for the Fertility Decline}

A fall in child mortality is often advanced as an important explanation for the decline in gross fertility, although in many models it also leads to an increase in net fertility (see Doepke, 2005) 22 We discuss the relationship between child mortality and fertility in SGA in greater detail when we turn to our discussion of the dynamics of mortality, but for now we note simply that net fertility did decline in the village: Table 4.1.1.1 displays figures for net fertility, by period, and Figure 4.1.1.1 shows the time path of net fertility. Here net fertility is defined as the average number of children per couple, minus the children who died during their first four years of life. The change in net fertility mirrors the fall in gross fertility, although it is about half as pronounced. The fall in net fertility suggests there is still variation to be explained, beyond the role of the decline in child mortality.

By far the most salient and empirically relevant explanation for the decline in fertility is the rise of education, leading to a substitution between quantity and quality of children. This idea has a long pedigree, but recent major contributions in this tradition stem from Unified Growth Theory (Galor and Weil, 2000, Galor, 2011, chapter 4). In our data, we confirm a general pattern often documented in the literature on demographic change: at the beginning of the period, high status households had more children than low status households, but this pattern disappears during and after the fertility transition. Table 4.1.1.1 and Figure A4.1.2.1 show trends in fertility by contemporary literacy status of the husband: for literate couples, fertility declines from 3.77 in Period I to 3.38 in Period II and 2.10 in Period III. While households headed by an illiterate husband start with a lower level of fertility, they display a more pronounced early decline: from 3.10 in Period I to 2.10 in Period II and 2.11 in Period III. In sum, we find little evidence in these raw statistics that more literate couples have a particularly pronounced role in the early decline in fertility.

Another explanation for the variation in marital fertility is the age of marriage. Figure 4.1.2.1 shows that the age of marriage for males was roughly stable throughout the sample period, while the age of marriage for females first rose by about 3 years between 1790 and 1820, and then fell back down

\footnotetext{
${ }^{21}$ We also note that the dating of the beginning of the fertility transition reported for France overall in Coale and Watkins is somewhat later than the date reported by other sources, such as Vallin (2006) or Blanc (2019).

${ }^{22}$ The fall in child mortality, however, may also lead to a reduction in net fertility if there is a precautionary motive for having children (see Kalemli-Ozcan, 2003).
} 
to the initial level after 185023 These dynamics open up the possibility that a later age of marriage for females contributed to the decline in fertility in the final decades of the 18th century ${ }^{24}$

To further examine the link between literacy and fertility, and to more rigorously assess the role of other determinants of fertility, we turn to regression analysis. Table 4.1.2.1 presents regressions for fertility at the household level, i.e. the dependent variable is a household's number of children. As before, we deal with migration by conditioning on migration score B being greater than $50 \%$ and linearly downweigh observations with low scores. We present a number of specifications with different regressors. Column 1 simply replicates the summary statistics from Table 4.1.1.1 showing average fertility by period. Column 2 adds literacy status of the father, showing that fertility is higher for more literate couples. Column 3 shows that this effect disappears after 1841, after the bulk of the fertility transition has occurred. In column 4, we add the mother's and father's age at marriage. We find, as expected, that a later age of marriage for the mother results in lower fertility, while the father's age at marriage is also negative but only significant at the $25 \%$ level. In column 5 , we add indicators for the social status of the household, finding that on average higher status households tended to have more children (the excluded social status category is lower class households). In column 6 , we add ambient child mortality. This variable changes through time, but is not household specific (it is a village-wide average). It represents the average probability that a child will die before reaching age 5 in SGA. We find that a lower probability of child death decreases gross fertility, in line with the discussion above and in line with findings in the literature on the fertility decline (see for instance de la Croix and Perrin, 2018)25 Finally, in column 7 we add all these variables together. Despite the substantially smaller sample (318 households), the estimated effects are stable when compared to those in the other columns. Moreover, estimates on the period dummies continue to show an average fall in household fertility from period to period, even after controlling for a number of direct determinants of fertility.26

\footnotetext{
${ }^{23}$ Breaking down age of marriage by social class, we find convergence. Before 1820, women's age at first marriage is higher for the lower and lower-middle classes (25 years old) than for the upper-middle and upper classes (22.1 years old). After 1820, the age of first marriage is about equal between the two (respectively, 26.1 and 24.5 years old). We find similar results when breaking down age of marriage by literacy status. This suggests that delaying marriage contributed to convergence in fertility between the lower / illiterate and upper / literate classes.

${ }^{24}$ The dynamics of the mother's age at the birth of her first and last child, are also interesting. They are displayed in Table A4.1.2.1. The mother's age at first birth is about 27 years in the first period and rises to about 29 in Periods II and III. The mother's age at the birth of the last child stays constant, around 35 years, across all three periods. A rough calculation suggests that the time interval between births is constant across Periods I and II and rises modestly in Period III. Thus the reduction in fertility is achieved mostly by delaying the first birth.

${ }^{25}$ However, the coefficient is sensitive to the inclusion of a trend, or of period-specific trends, in the regression. Whether it is ambient child mortality that matters or some other time varying factor captured by the trend is open to debate. All the other coefficient estimates are not sensitive to the inclusion of a trend or period-specific trends.

${ }^{26}$ In the Appendix, Figures A4.1.2.3 to A4.1.2.7, we further explore the sensitivity of these results to different cutoffs for the migration score. We reestimate the fertility regressions excluding observations with a migration score B smaller than $x$, where $x$ varies between $25 \%$ and $75 \%$. The estimated coefficients on the main variables of interest are very stable.
} 
In sum, these regressions reveal 1) a positive effect of literacy on fertility, which disappears after 1830; 2) a positive effect of ambient child mortality on fertility; 3) a negative effect of the mother's age of marriage on fertility; 4) evidence that even after these factors are accounted for, fertility declined for independent reasons from each period in our analysis window to the next. Combining these results with the trends in marriage age, child mortality and literacy, we can conclude that a later age of marriage and declining child mortality were likely contributing factors to the decline in fertility, since the period of declining fertility in SGA coincides with rising female age of marriage and declining child mortality ${ }^{27}$ On the other hand, the bulk of the fertility transition occurs before the major increase in literacy (further explored below). The data reveals that most of the fertility decline occurred within the two decades that followed the French Revolution, suggesting that the social turmoil and cultural change around this momentous event may have contributed to changing fertility norms within the village. 28

\subsection{Mortality}

\subsubsection{Infant and Child Mortality}

Figure 4.2.1.1 displays the time path of infant and child mortality, using the households database. The series show a pronounced decline in both series. Child mortality falls from about $25.4 \%$ in the Period I to $12.9 \%$ in Period III. Most of the decline occurs during the period 1775 to 1840 . While we do see a decline in mortality for ages 1 through 4, most of the decline in child mortality is attributable to the decline in infant mortality. Interestingly, the decline in infant and child mortality is similar across literacy levels and social classes. For instance, in Period I, child mortality was $25.0 \%$ for lower class, $24.4 \%$ for the lower-middle class and $25.6 \%$ for the upper-middle and upper classes. In Period III, the corresponding numbers are $14.1 \%, 11.3 \%$ and $16.8 \%$. None of these differences are statistically significant ${ }^{29}$ The end-of-period numbers for SGA line up well with those in Barbieri (1998), who gives a child mortality rate of $14.5 \%$ for France overall in 1901.

We lack data to evaluate the causes of the decline in child mortality, but the uniformity of the decline across literacy status and classes suggests that generalized improvements in health, hygiene and

\footnotetext{
${ }^{27}$ Brée and De La Croix (2019) argue that the evolution of childlessness during the fertility transition can help discriminate between theories of the fertility transition that emphasize female empowerment, a rise in materialism or changes in the returns to human capital. The latter hypothesis implies a fall in childlessness while the first two would imply a rise in childlessness. Using data from Bardet (1983), they show that the fertility transition in the city of Rouen in Normandy was associated with a rise in childlessness. In our village, we also find a rise in the childlessness rate in the first decades of the 19th century, after conditioning on migration score $s_{1}=1$ (indicating a low probability of migration for the household - see Appendix 1.2). This is consistent with stories that emphasize changes in norms such as a rise in materialism and a rise in female empowerment - both of which could be the product of the age of Enlightenment and the French Revolution.

${ }^{28}$ For evidence on the cultural diffusion of fertility norms across Europe, see Spolaore and Wacziarg (2014).

${ }^{29}$ In Period I, child mortality was $24.0 \%$ for households with illiterate husbands, and $31.1 \%$ for literate households. In Period III these averages were $10.0 \%$ and $14.7 \%$, respectively. Again, these differences are not statistically significant.
} 
nutrition might be leading causes. For an in-depth treatment of the causes of the decline in mortality, both in historical contexts and for currently developing countries, see Cutler, Deaton and Lleras-Muney (2006). These causes include improved nutrition, receding infectious diseases (including tuberculosis and smallpox) and improvements in medical treatment and public health measures. Additional causes like vaccination and urbanization are not major factors in our context: the advent of vaccination happened after the bulk of the decline of mortality in SGA, and urbanization obviously could not have been a direct factor at the village level.

The decline is likely to have had wide-ranging consequences. A major consequence is on fertility behavior. In his classic book, Preston (1978) outlined four major mechanisms linking child mortality and fertility: (1) the child replacement effect, whereby households wish to replace deceased children ex post; (2) the insurance effect, whereby households may ex ante overshoot their target number of children to make sure the desired number survive; (3) the physiological effect, whereby the death of a child results in a shorter post-delivery period of infertility (due to the interruption of breastfeeding); (4) the societal effect, which is less cleanly defined, but refers generally to the effect of high child mortality on marriage age and other societal norms with a bearing on fertility 30 The decline in child mortality might also have affected investment in child quality, and thereby played a role in the gradual improvement in education and human capital in SGA documented in the next section. Kalemli-Ozcan, Ryder and Weil (2000), for instance, show that lower mortality raises the relative return to investing in child quality rather than quantity, by lengthening the horizon over which the returns are realized, leading to faster human capital accumulation.

Van De Walle (1986, chapter 4) argues there is no dispositive evidence that the decline in mortality and fertility in France were related, despite theories emphasizing the link. Her data on child mortality starts around 1830, after the start of the fertility transition in France. As Wrigley (1985) also emphasizes, there is not much data on child mortality in 18th Century France. In this context, our village-level evidence is noteworthy as we are able to relate contemporary declines in child mortality to fertility behavior.

\subsubsection{Adult Life Expectancy}

Beyond child mortality, progress in life expectancy was steady in SGA over our period of analysis. Average age of death conditional on reaching age 20 (our measure of life expectancy at 20) is displayed in Figure 4.2.1.1. For both males and females, this variable rises steadily from about 45 in 1750 to over 60 in 1880 (Figure A4.2.2.1). There is no statistically significant difference in the levels and dynamics of life expectancy for males and females. We looked more closely at a rough measure of maternal mortality: in the households database, the ratio of women who died within 6 months of giving birth to the number of live births in a given period falls from $2.05 \%$ in Period I to $1.85 \%$ in Period II and

\footnotetext{
${ }^{30}$ These mechanisms are well summarized in Van De Walle (1986) and Palloni and Rafalimanana (1999).
} 
$1.42 \%$ in Period III 31

Figure 4.2.1.1 compares average age of death conditional on reaching age 20 with average age of death, without conditionality (i.e., life expectancy at birth). The latter is much lower, by about 20 years on average, largely reflecting the high incidence of child mortality ${ }^{32}$ There was some convergence between the two series as reductions in child mortality were more pronounced than reductions in overall mortality over the period under scrutiny. Life expectancy at birth rose particularly fast in the three decades after 1810. As was the case with child mortality, the increase in adult life expectancy is likely to have had important effects on a variety of outcomes by lengthening the horizon over which the returns to investment in human and physical capital are realized (Ben Porath, 1967, Lorentzen, McMillan and Wacziarg, 2008).

\section{Change and Persistence in Literacy}

\subsection{Institutional Background and Trends in Literacy}

We start with some institutional background on education in SGA during our sample period. Prior to 1789 , the village priest was in charge of education (Marcadé, 1899), and it is probable that, in addition, higher status households home schooled their children. It is likely that the priest chose a few boys to receive basic literacy instruction. As revealed by the civic records, some of these would make it to the status of vicar ("vicaire"), the priest's deputy ${ }^{33}$ A major event in the educational history of SGA occurs in 1834: According to the municipal budget, a schoolteacher was appointed in that year, following the Guizot Law of 1833 subsidizing primary education for boys. Among other provisions, the Guizot Law: 1) required the construction of a school for boys and the continued employment of a teacher in every municipality with more than 300 inhabitants, 2) allowed for the subsidization of such schools by the départements, in case municipalities were unable to finance them on their own (in reality this implied a complex annual bargaining process between the municipality and the départements, resulting in a cost sharing outcome), 3) guaranteed free education for poor (male) children 34

\footnotetext{
${ }^{31}$ We found no differences in the dynamics of life expectancy across social classes: lower and lower-middle classes have lower life expectancy than upper-middle and upper classes (by about 4.5 years on average over the sample period), but both categories show similar improvements over time.

${ }^{32}$ The data we compiled for SGA is comparable for that obtained from a broader sample of French villages and towns in Blayo (1975). In that sample, male life expectancy at birth in the decade starting in 1740 was 23.8 , and 25.7 for females. It rises to 38.3 (males) and 39.3 (females) in the 1820s. Average age of death in SGA was 20.4 in the 1740 s and 35.9 in the 1820 s.

${ }^{33}$ Since we base our pre-Revolution data on parish records, we know the identities of the successive priests and vicars. Remarkably, only two priests were successively in office from 1730 to 1774: Julien Le Saulnier (from 1730 until 1756), then Jean Le Saulnier from 1758 to 1774 . These were followed by three priests with shorter tenures until the Revolution and at that stage we lose the ability to identify the priest.

${ }^{34}$ Squicciarini and Voigtländer (2016) show that areas of France with a greater density of subscriptions to Diderot's Encyclopedia, a proxy for the influence of knowledge elites, experienced faster schooling growth over the period 1829-
} 
For 1834, a special tax was passed to finance the cost of the schoolteacher. The special tax levied an annual sum of 99.42 Francs from village taxpayers (for comparison, in 1833 total municipal revenues were 174.65 Francs, so the cost of the schoolteacher in 1834 amounted to $57 \%$ of the previous year's revenues). The municipality received an additional education subsidy from the département of 160.58 Francs, as per the Guizot Law of 1833. The total was divided into paying for the teacher's lodging (60 Francs) and salary (200 francs). The share of the subsidy in the total cost is substantial. The boys' school was built in 1841 about 300 meters from the village center. Its cost was 3,000 Francs, financed by municipal savings over several years as well as from an external subsidy 35 In 1888 , the school moved inside the village. Following the Falloux Law in 1850, a school for girls was established in 1859.

Figure 5.1.0.1 displays the time path of literacy, based on the households database. Literacy in Period I is at a very low level of about $20 \%$ for males, and lower for females. We see a slightly rising pattern of male literacy at the end of Period I, a dip in literacy immediately after the Revolution, and a steep take-off in Period III - likely due to the aforementioned supply of educational services triggered by the school construction and hiring of a full time schoolteacher 36 Literacy reached $85 \%$ for females and $86.25 \%$ for males on average in the last 20 years of our sample period (1875-1895). These numbers are completely in line with literacy levels and trends in Mayenne overall (Statistiques Générales de la France, 2011b, Furet and Ozouf, 1977).

Figure 5.1.0.1 also breaks literacy down by social class. The figure reveals several interesting facts: literacy rises early for the upper classes, reaching a level close to $100 \%$ by 1830 . Literacy also rises early for skilled craftsmen (who comprise all of the socioeconomic class that we label as "upper middle"), with a structural break roughly in 1820, rising from $40 \%$ prior to that date to about $80 \%$ in 1850 . Finally the lower and lower-middle classes are those most likely to see their literacy affected by the hiring of a schoolteacher and construction of the school: for them, literacy takes off more steeply after 1840. Reassuringly, while our classification of socioeconomic classes relies entirely on the underlying profession, it is reflected in literacy status: lower classes throughout have lower literacy than the lowermiddle classes, who in turn have a lower literacy than the upper-middle, etc. Convergence in literacy status between classes is substantial but the lower class still lags behind by the end of our sample period.

1850. Looking at their data, we found that the département of Mayenne had zero subscribers. It is indeed plausible that the construction of the school and hiring of a schoolteacher in SGA was a direct effect of the Guizot Law rather than the indirect effect of local demand for schooling by knowledge elites.

${ }^{35}$ It appears that at least $50 \%$ (most likely two thirds) of the cost was covered by subsidies from the département or the central government.

${ }^{36}$ One needs to be careful in making statements about the timing of the rise in literacy. In Figure 5.1.0.1, literacy is recorded as of the date of marriage or birth of the first child, which tends to be about $10-15$ years after the bulk of schooling is obtained. A statistically significant take-off in literacy is observed after 1850, and the hiring of the full-time schoolteacher occurred in 1834. So the rise is schooling is roughly congruent with the coded timing of literacy in the data. 


\subsection{The Intergenerational Transmission of Literacy}

A unique feature of our data is the ability to link outcomes across generations. In this subsection we examine the extent of the intergenerational linkages in literacy status. We can thereby assess the degree of persistence in literacy status across generations. Table 5.2.0.1 provides the literacy transition matrix for the overall sample period ${ }^{37}$ We see a substantial degree of intergenerational persistence in literacy status. $71.1 \%$ of those whose father was illiterate are illiterate themselves, while $72.4 \%$ of those with a literate father are literate.

Table 5.2.0.1 also breaks down these transition probabilities by period. As implied by the rising literacy trend, intergenerational literacy mobility rises from period to period, with the greatest contrast occurring between Period II and Period III, i.e. before and after the hiring of a full time schoolteacher and construction of the school. In Periods I and II, over $82-85 \%$ of those with an illiterate father remain illiterate, so only $15-18 \%$ of those with an illiterate father become literate. The reversion rate to illiteracy is high, at around $40 \%$. In Period III, only $40.3 \%$ of those with an illiterate father remain illiterate, and over $90 \%$ of those with a literate father remain literate. Early in the sample period, then, literacy was confined to a small share of the population and passed on from one generation to the next. Later, the rising literacy trend reduced the intergenerational transmission of illiteracy.

\subsection{Regression Analysis of the Literacy Transition}

We conclude this section with a discussion of the econometric determinants of the rise in literacy. Table 5.3.0.1 displays marginal effects from probit regressions of literacy status on a set of determinants. The first four columns are for a sample of males that includes at least one intergenerational link, in order to observe the father's literacy. The first row reports a robust, highly significant effect of the previous generation's literacy status on literacy: the effect of the father's literacy status is a $0.27-0.43$ difference in the probability of being literate. Dummies for Period II and III are included in columns $2-5$, showing that the increase in literacy becomes significant only after the establishment of a permanent school in 1841 38 This again suggests the important role of educational supply factors. Columns 3 and 4 include dummies for socioeconomic class (the omitted category is lower classes). The marginal effects are all sizable and positive and higher class status is associated with higher literacy levels, replicating the findings obtained from simple averages in Figure 5.1.0.1. Column 4 also includes

\footnotetext{
${ }^{37}$ The sample for which we observe literacy status for more than one generation is smaller than the sample for which we observe literacy overall in the households database. To address the possibility of sample selection, Figure A5.2.0.1 displays the path of literacy for the whole sample, weighed by migration score, and for the subsample with observations for more than one generation. The two series overlap nearly perfectly, suggesting that the sample of households for which literacy status is available for more than one generation is representative of the overall sample.

${ }^{38}$ Appendix Table A5.3.0.1 runs a probit regression of literacy on the father's literacy, separately for each of periods I, II and III. The coefficient on the father's literacy status is steady across the first two periods (at about $0.40-0.45$ ) and falls significantly (to 0.33) in Period III. This is as one would expect since the bulk of the rise in literacy occurs in the third period.
} 
life expectancy at 20 at the village-wide level, to capture the effects of longevity on human capital investment (Ben Porath, 1967). A longer life expectancy has a positive though insignificant effect on literacy. Finally in column 5 we include females, roughly doubling the sample. All of the previous estimated effects remain robust, and additionally we document a significant 13.7 percentage point difference in the probability of being literate between males and females, on average over the sample period.

\section{Change and Persistence in Professions and Socioeconomic Status}

\subsection{Occupational and Class Structure}

In contrast to the profound changes experienced in terms of demographics and literacy, there is a high degree of persistence in occupational and class structure in SGA over our sample period. To assess the evolution of occupations and social classes, we rely on the classification described in Section 3.1.4. Figures 6.1.0.1 and A6.1.0.1 display the evolution of the shares of various classes and occupations over time, for males and females separately. Figure 6.1.0.2 provides information for social classes. The shares of various classes barely budges during the entire time period under study. For males, about $60 \%$ of observations belong to the lower-middle class, and another $20-25 \%$ to the lower class. There is a slight increase in the shares of the upper middle class (skilled craftsmen) and upper class (bourgeois), after 1840, but none of these changes are statistically significant. For females, a high degree of social stability is also observed: the change from textile worker to farmer occurs within the lower-middle class, to which both these occupations belong. We see about $75 \%$ of females in the lower-middle class throughout, and another $15-20 \%$ in the lower class.

Figure A6.1.0.1 shows considerable stability in the shares of various occupations ${ }^{39}$ For males, by far the most prevalent occupation is farmer, which encompasses about $50 \%$ of the population throughout (farmers include those labeled as cultivator, peasant laborer, cropper and sharecropper). There is a small textile industry in the village, and about $15-20 \%$ of male employment is in this industry, but it declines after 1840 to about 5\%. As a result, the share of farmers actually increases slightly, late in the sample period. Shares of the other occupations display a high degree of stability throughout the period for which occupation data is available (1780 to 1895 for males). For females, we also see considerable stability, except for a more pronounced decline of occupations in the textile industry and a correspondingly steeper increase in the share of day laborers. These steeper changes are due to the higher share of the female population initially employed in the textile industry - about

\footnotetext{
${ }^{39}$ We lack time series data on income for various occupations but Table A6.1.0.1 provides a snapshot for 1852 , for which several sources allow us to reconstruct the cross section of occupational incomes. A dress maker (lower-middle class) made 75 centimes per day, which is anywhere from $\$ 183$ to $\$ 256$ per month (depending on assumptions about the number of days worked). A day laborer (lower class) made $\$ 122-\$ 171$ per month. The village schoolteacher made $\$ 246$ per month, but this more than doubled after 1852. These occupational incomes line up well with our categorization of occupations into classes.
} 
$35 \%$ in 1840, falling to $20 \%$ in 1895 . The corresponding shares of females recorded as farmers rises from under $40 \%$ to over $50 \% 40$

In sum, there is virtually no sign of structural transformation in the village, if anything there is a slight increase in the share of farmers after 1850.

\subsection{Occupational and Class Mobility}

In this subsection we assess the degree of intergenerational transmission of class and occupation in SGA, and how it changed over time. To do so, we rely on observations from the households database for which occupation and class are recorded for more than one generation 41 An easy way to assess the overall degree of occupational and class mobility is to plot the share of sons with the same occupation or social class as their fathers. Figure A6.2.0.2 plots these series for occupation and class. For occupations, the share fluctuates between $50 \%$ and $75 \%$ and remains stable around $60 \%$ throughout the period 1780-1895. There is an increase in mobility after the French Revolution and a stabilization thereafter. We find similar patterns for class mobility, though the increase in mobility after 1789 is less pronounced than for occupations.

Table 6.2.0.2 (Panel A) provides a transition matrix for the four classes, arraying occupations of the father (row 1) and of the son (column 1). Cells at or near the diagonal have high entries. For instance the probability of being in the lower middle class conditional on having a father in the lower middle class is $81 \%$ (an additional $15.6 \%$ of those with fathers in the lower-middle class have sons in the lower class). Transitions from lower to upper classes are very uncommon. Only 2 individuals with fathers in the lower class, out of 61, ended up in the upper class. Transitions in the other direction are more common, as about $39.4 \%$ of those with fathers in the upper class end up in the lower middle class. Turning to time variation in class mobility, Table 6.2.0.2 also provides two separate transition matrices for 1790-1840 (Panel B) and 1841-1895 (Panel C). There is not much change in the degree of social mobility between these two periods. There is a slight increase in the probability of transitioning from the lower to the lower-middle class, and a slight decrease in downward mobility from the upper middle

\footnotetext{
${ }^{40}$ Female occupations and male occupations are closely related. In $51 \%$ of the cases, the occupation recorded for the two members of a couple is the same (e.g. both are recorded as farmers). When the two deviate, the most frequent case is that the wife is employed in textiles, while the husband is a farmer. While male and female occupations are not perfectly aligned, for $72 \%$ of couples, wives and husbands belong to the same social class. For the remainder, it is usually the case that one belongs to the lower class and the other to the lower-middle class. Thus, there is a high degree of assortative mating, both in terms of occupations and social classes.

${ }^{41}$ The sample for which we observe occupation / class status for more than one generation is smaller than the sample for which we observe occupation / class overall in the households database. To address the possibility of sample selection, Figure A6.2.0.1, compares the time path of various series for the whole sample, weighed by migration score, and for the subsample with observations for more than one generation. The series are: 1) the share of the lower class, 2) the share of the lower-middle class, 3) the share of the upper middle and upper classes, and 4) the literacy rate. In all four cases, the local polynomials are always inside each others' confidence intervals, suggesting that the sample of households for which occupational / class status is available for more than one generation is representative of the overall sample.
} 
class, but these changes are not very significant due to the small number of cases. The analysis at the level of classes reveals a high degree of persistence in the degree of intergenerational class mobility. This persistence in mobility mirrors the persistence in the structure of professions and classes documented in the previous sub-section.

Table A6.2.0.1 displays the transition matrix for occupations. Several things stand out. First, entries at or close to the diagonal once again contain high percentages. For instance $73.8 \%$ of sons whose father was a farmer were also farmers. Most of the rest (14.8\%) were day laborers. Similarly $59.4 \%$ of those with a father working in the textile industry also worked in the textile industry. Second, there are very few entries farther from the diagonal, indicating that it was very unusual for someone with a father with low skill / low status profession to move substantially up the ladder (and similarly for downward mobility). One exception is that we see a few examples (11) of bourgeois fathers whose sons were farmers. Given the high degree of stability in occupational structure over time, there is not much scope for net upward or downward mobility. Overall, this table paints the picture of a village with a very high rate of intergenerational transmission of occupations ${ }^{42}$

\subsection{Determinants of Social Class}

To analyze the determinants of social class, we conduct a regression analysis of generation $t$ 's social class rank, using the households database 43 Regression results are presented in Table 6.3.0.1. The independent variables include the class score of generation $t-1$ as well as the literacy status of generation $t$. The sample is limited to sons for columns 1-4 and includes daughters in columns 5 and 6 (period $t-1$ data is based on fathers only). The results suggest a high degree of intergenerational class persistence. Across all specifications, a 1 unit difference in generation $t-1$ 's class rank is associated with a difference in generation $t$ 's class rank of anywhere between 0.4 and 0.5. Not surprisingly, generation $t$ literacy positively affect the class rank. Column 4 shows no evidence of a change in the autoregressive coefficient on class rank between Period II and Period III, indicating stability in intergenerational mobility between periods (Period I is excluded from the specifications of columns 3-6: there are only 28 observations in Period I, since we use class and occupations data starting in 1780). Finally, these findings do not differ between sons and daughters.

To ease interpretation, we also ran linear probability models to explain either lower class status or upper / upper middle class status (Tables A6.3.0.1 and A6.3.0.2). In the first case the dependent

\footnotetext{
${ }^{42}$ Table A6.2.0.1 also displays occupational transition matrices at two different dates (where dates correspond to the date of formation of households): Panel B for the period 1790-1840 and Panel C for 1841-1895. Results should be taken cautiously because there are not many observations in many of the cells, but overall we do not see any dramatic changes in the degree of intergenerational occupational mobility between periods. Diagonal or close to diagonal entries are large in both periods. We see relatively high rates of mobility for sons whose fathers were bourgeois, in both periods.

${ }^{43}$ Lower class is coded as 1 , lower middle class is coded as 2, upper middle class is coded as 3 and upper class is coded as 4. For ease of interpreation, the dependent variable used in Table 6.3.0.1 is based on these ranks, not on the class scores discussed in Section 3.1.4.
} 
variable takes on a value of 1 if generation $t$ is lower class, zero otherwise, and in the second case the class indicator is 1 if generation $t$ is either upper middle or upper class, zero otherwise. These regressions also display a large degree of intergenerational class persistence. For instance, for every unit increase in the father's class rank, the probability of generation $t$ being in the lower class falls by anywhere between $10 \%$ and $15 \%$, depending on the specification. Similarly, for every unit increase in the father's class rank, the probability of generation $t$ being in the upper or upper-middle class rises by anywhere between $13 \%$ and $20 \%$. In addition, generation $t$ literacy predicts class status positively.

To summarize, our regression analysis of the class rank of generation $t$ confirms a very high degree of intergenerational class persistence in SGA over the period 1780-1895. Social mobility did not change materially between Periods II and III ${ }_{44}^{44}$

\subsection{Land Ownership and Local Leadership}

We conclude our discussion of socioeconomic mobility in SGA by discussing the evolution of village elites. We define elites as both landowners and families appearing on the municipal council. We document tremendous persistence in elite status in the village.

Land ownership patterns in the village are characterized by an increase in the number of landowners from a low base (Figure 6.4.0.1). There were 3 landowners recorded in Period I, 9 in Period II and 24 in Period III (these numbers may slightly understate the number of landowners because some may not have married during these periods, and others may not have been recorded as landowners on marriage records, which form the basis of our count). The relative fractionalization of land ownership can in principle come from divisions resulting from inheritance. For those outside of nobility (" roturiers"), the legal standard is based on absolute equality between heirs: each heir had to receive an absolutely equal share of the inherited estate (Bonin and Langlois, 1995, pp. 52-53). This standard of absolute equality was in force in the Mayenne region at least since the 15th Century. For those in the nobility, and other large landowners, inheritance practices were less egalitarian, and families strove to maintain the integrity of landholdings by favoring one heir (De Brandt, 1901, pp. 186-189). Jaurès (1901) contains a limpid explanation of the standard of absolute equality in French inheritance laws, and describes how the Revolution led to its spread across France and across social classes. This standard had a tendency to foster the fractionalization of estates among heirs, compared to other inheritance rules in place in other regions of France, where specific heirs could be favored. Thus, changes in legal standards relating to inheritance, following the French Revolution, may account at least in part for the observed rise in the number of landowners in SGA.

The relative dispersion of land ownership occurs in Period III and is not associated with a significant change in social mobility, as already discussed. Surnames that were recorded as landowners in at least two of our three periods include Leclerc, Pouteau, Robert and Thoumin. Two of these last names

\footnotetext{
${ }^{44}$ If we compare social mobility using households formed between 1780 and 1810 to those formed between 1865 and 1895, we also find no statistically significant difference in the extent of social mobility.
} 
(Pouteau and Thoumin) are those of signatories of the cahier de doléances in 1789. Similarly, six of the twelve mayors of SGA between 1793 and 1938 share the same last names - three from the Pouteau family, two from the Lerclerc family, and one from the Thoumin family (see Table A6.4.0.1). Out of twelve mayors of SGA between 1793 and 1938, only three shared a last name never recorded as owning some land.

An analysis of the surnames on the municipal council reveals a similar persistence of elite status 45 Figure 6.4.0.2 plots the share of surnames appearing on the municipal council that were also recorded as high status at other junctures. In SGA, there were between 6 and 13 members on the municipal council between 1831 and 1887 (averaging 8.94 members). There is significant overlap between the last names of the members of the municipal council and the names of top village taxpayers in 1840 and 1891. There is also significant overlap with landowner families and signatories of the cahier de doléances. In sum, the evidence we have on high status families is consistent with a high degree of persistence in elite status throughout the period.

\section{The Sequencing of Modernization}

\subsection{Change and Persistence in the Age of Modernization}

In this section, we articulate the sequencing of modernization over 1730-1895 in SGA by combining the facts documented in the previous sections concerning institutional change, the demographic transition, the accumulation of human capital and changes in social mobility. We do so in order to assess the process whereby modernization occurred in the village. We start in Table 7.1.0.1 by characterizing the estimated dates of transitions for the main variables of interest. The table lists the dates of the first sustained decrease or increase for fertility, child mortality, life expectancy, literacy and class immobility, in the order of the dates of transition. We present the dates as ten-year intervals, reflecting uncertainty on the precise timing of the transitions. Figure 7.1.0.1 presents the full time series of literacy, class immobility, fertility and net fertility, as defined in the preceding sections.

Several observations stand out of the table and figure. Demographic change came first. The table shows that the increase in life expectancy at age 20 first experienced a sustained $10 \%$ increase in the decade between 1742 and 1751 (life expectancy increases at a steady rate throughout our sample period). The corresponding dates for decreases in child mortality and fertility are the decades starting in 1783 and 1794, respectively. Figure 7.1.0.1 shows that by 1810, the bulk of the fertility transition had already occurred. The rise in literacy occurs at least two decades later: we date the first sustained $75 \%$ increase in the literacy rate to the decade 1829-1838 - which includes the opening of the school. Finally, there is no transition in class structure - which remains roughly stable throughout the period. This reflects our preceding discussion about the absence of changes in both socioeconomic and class

\footnotetext{
${ }^{45}$ For a important analysis of the persistence of socioeconomic status associated with surnames in the context of England, see Clark and Cummins (2014).
} 
mobility in SGA throughout the sample period.

How can we interpret these findings in light of the major theories of modernization outlined in Section 2.1? In SGA, it appears that the fertility transition preceded by a long time any change in the trade-off between the quality and the quantity of children, and to have coincided with major intellectual and institutional upheavals: the effects of the "Age of Enlightenment" and of the French Revolution, with the consequent decline in the influence of the Church and the greater reliance on reason relative to religion and superstition 46 The rise in literacy seems to have responded mostly to changes in national policies toward schooling rather than village-level structural transformations leading to changes in the returns to human capital. Indeed, there was no significant structural transformation at the village level, and no evidence of major technological improvements in agriculture until the end of our sample period. In sum, forces of cultural diffusion of behavioral norms emerging outside SGA and more generally the effect of factors external to the village, such as the policy changes triggered by institutional upheavals following the French Revolution, are most likely the sources of demographic change and of the subsequent rise in literacy.

\subsection{Illustrative Lineages}

In this section, we provide two case studies of lineages that originated in SGA, to illustrate the general conclusions on modernization reached using our comprehensive database. We chose two paternal lineages, one from the Genest family, which remained in the village throughout the sample period, the other from the Rousseau family, which migrated to the nearby village of Martigné in the 1810s. We are able to follow both lineages throughout the sample period.

Tables A7.2.0.1 and A7.2.0.2 provides as much information as we could gather from our database (and complementary genealogical research from the same sources) on these two lineages. We follow lines of paternity, but not necessarily of the firstborn boy, as the goal is to maximize the time span of our lineages. We comment on the evolution of these two lineages with respect to migration, demographics, human capital, and social mobility.

Both lineages originate in SGA. Every head of household of the Genest lineage was born in SGA. For the Rousseau lineage, this is true only until the 4th generation. The head of household in the 5 th generation, Victor Rousseau, was born in the nearby village of Martigné, $8.5 \mathrm{~km}$ away. We were able to follow this lineage further in this nearby village. This example illustrates the prevalence of migration to nearby locations due to marriage, and demonstrates the need to adjust estimates for migration (Section 3.3).

Both lineages feature high initial fertility. Generation 1 of the Genest lineage involved 16 children, 6 of whom died before age five, and the next two generations involved 7 and 9 children respectively. Similarly, the first three generations of the Rousseau lineage involved an average of over 9 children per

\footnotetext{
${ }^{46}$ Pinker (2018) contains a recent treatment of the long run effects of the Enlightenment.
} 
generation. It is not until the generation born in the late 18th century that we can see an inflexion in fertility. Generation 4 (born in the 1780s or 1790s) in both lineages feature 5 or 6 children, and then 3 or fewer in subsequent generations. This follows the pattern uncovered in the broader sample. Child mortality also falls in later generations.

The pattern of literacy is different between our two lineages. We have evidence that the head of household of the Genest lineage was literate from the first generation on. In contrast, the transition to literacy for the Rousseau lineage started in generation 5 (born in 1814) - i.e. one generation after the inflexion in fertility, yet before the construction of the village school, so a bit earlier than the big inflexion in literacy observed in our large sample (Figure 5.1.0.1).

While information on occupation is missing for the first two generations of the Genest lineage, starting in the 3rd generation we are able to ascertain that this was a family of farmers (" cultivateur" - a lower-middle class occupation in our classification). This remained the case till the 5th generation, when we stop tracking this lineage. We have more information on occupations for the early generations of the Rousseau lineage. They were tailors, from father to son until the 5th generation, illustrating the high degree of intergenerational persistence in occupations and socioeconomic status.

In sum, these lineages provide detailed illustrations of various conclusions reached in previous sections of this paper uaing the broader sample. Fertility starts to decline steeply in the final years of the 18th century. Literacy rises in the first decades of the 19th century. There is little social mobility in SGA, with professions and social status transmitted very predictably from generation to generation.

\section{Conclusion}

In the decades around the French Revolution, France underwent a process of institutional, cultural and demographic modernization, creating the conditions for a sustained increase in standards of living. In this paper, we provided a detailed microeconomic analysis of this process of modernization in the context of a single village in Western France, Saint-Germain-d'Anxure. Using data on the characteristics of households inhabiting this village between 1730 and 1895, we described the transformations in demographic outcomes, literacy, and socioeconomic status that occurred in the village. Doing so, we shed light on theories explaining the advent of modernity, carefully controlling for migration and exploiting intergenerational structure of the data whenever possible.

Our main conclusion is that modernization in SGA stemmed most plausibly from the cultural changes that accompanied the Age of Enlightenment and the institutional upheaval that resulted from the French Revolution. We find little evidence that, at early stages, the main primitive explaining modernization was technological innovation or structural change. The village, instead, was buttressed by external forces such as the diffusion of new demographic modes of behavior and educational mandates from the central government that led to both reduced fertility and increased literacy. We find no evidence of major changes in technology or the structure of production, and indeed socioeconomic 
mobility and the occupational structure of the village remain roughly constant throughout the period under study. From generation to generation, households carry out similar productive activities and maintain similar positions on the social ladder. Yet they transition to lower fertility in the waning years of the 18th century, and gradually become more literate, with major increases in literacy occurring after the appointment of the schoolteacher in 1833 and the construction of the school in 1841.

Our detailed analysis of a single village illustrates how it is possible to conduct a quantitative microeconomic analysis of a historical process of economic development in a country that successfully modernized. Generalizing these methods beyond a single village would allow economic historians to trace households movements across villages, as the result of marriage and other causes of local migration. As more and more civil records are digitized and made available, a systematic coding of all available information for France and beyond should become possible. Such a task would represent a colossal undertaking, yet it would allow social scientists to apply methods of analysis currently reserved to contemporary developing countries to settings where societies successfully transitioned from stagnation to modernity. It is likely that, in the process of carrying out this enormous task, multiple paths to development and modernity will emerge. The English path most plausibly conformed to a pattern whereby technological innovation and the changing returns to human capital, followed by demographic change, drove modernization. In contrast, France achieved roughly the same standards of living by putting demographics first, education second, and industrialization last. 


\section{References}

Acemoglu, D., S. Johnson and J. A. Robinson (2001). "The Colonial Origins of Comparative Development: An Empirical Investigation", American Economic Review, 91(5), pp. 1369-1401.

Acemoglu, D., D. Cantoni, S. Johnson and J. A. Robinson (2011). "The Consequences of Radical Reform: The French Revolution", American Economic Review, 101(7), pp. 3286-3307.

Allen, R. C. (2003), "Progress and Poverty in Early Modern Europe", The Economic History Review, 56: 403-443

Bairoch, P. and G. Goertz (1986). "Factors of Urbanization in Nineteenth Century Developed Countries", Urban Studies, 23(4), pp. 285-305.

Barbieri, M. (1998). "La Mortalité Infantile en France", Population, 53(4), pp. 813-838.

Bardet, J. P. (1983). Rouen aux XVIIe et XVIIIe Siècles: Les Mutations d'un Espace Social. Paris: SEDES (2 volumes).

BDCassini (2017). Population of French Villages, 1793-1999, available at http://cassini.ehess.fr/. Paris: EHESS.

Blayo, Y. (1975). "La Mortalité en France de 1740 à 1829", Population, 30(1), p. 123-143.

Becker, G., Murphy, K. and Tamura R. (1990). "Human Capital, Fertility and Economic Growth", Journal of Political Economy, 98(5-2): S12-37.

Ben-Porath, Y. (1967). "The Production of Human Capital and the Life Cycle of Earnings", Journal of Political Economy, 75(4), pp. 352-365.

Blanc, Guillaume (2019). "Modernization Without Development? Evidence from 400 Years of Crowdsourced Historical Data", Working Paper, Brown University.

Bonin, S., C. Langlois (1995), Atlas de la Révolution Française, vol. 8: Population. Paris: Editions de l'E.H.E.S.S.

Brée S. and De la Croix D. (2019), "Key Forces Behind the Decline of Fertility: Lessons from Childlessness in Rouen before the Industrial Revolution", Cliometrica, forthcoming.

Coale, A. J. and Watkins, S. C. (1986). The Decline of Fertility in Europe, Princeton University Press. Clark, G. and Cummins, N. (2014). "Intergenerational Mobility in England, 1858-2012. Wealth, Surnames, and Social Mobility", Economic Journal, 125(582), pp. 61-85.

Clark, G. (2014). "The Industrial Revolution," Chapter 5 in P. Aghion and S. Durlauf, eds, Handbook of Economic Growth, vol. 2: 217-262. North Holland: Elsevier.

Cummins, N. (2013). "Marital Fertility and Wealth During the Fertility Transition: Rural France, 1750-1850", Economic History Review, 66(2), pp. 449-476.

Cutler, D., Deaton A. and Lleras-Muney A. (2006). "The Determinants of Mortality", Journal of Economic Perspectives, 20(3): pp. 97-120.

De Brandt, A. (1901). Droit et Coutumes de la France Rurale en Matière Successorale, Paris: Librairie de la Société du Recueil Général des Lois et des Arrêts. 
de la Croix, D. and F. Perrin (2018). "How Far Can Economic Incentives Explain the French Fertility and Education Transition?" European Economic Review, 108, pp. 221-245.

de la Croix, D., Schneider, E. and J. Weisdorf (2018). "Decessit Sine Prole: Childlessness, Celibacy, and Survival of the Richest in Pre-Industrial England", Working Paper, Université Catholique de Louvain.

Doepke, M. (2005), "Child Mortality and Fertility Decline: Does the Barro-Becker Model Fit the Facts?", Journal of Population Economics, 18(2), 337-366.

Doepke, M. (2010). "Growth Takeoffs," in S. Durlauf and L. Blume (eds.), Economic Growth, The New Palgrave Economics Collection, pp. 133-140.

Fine-Souriac, A. (1978). "Mortalité Infantile et Allaitement dans le Sud-Ouest de la France au XIXe Siècle," Annales de démographie historique, 1978(1), pp. 81-103.

Fleury M. and Henry, L. (1956). Des Registres Paroissiaux à l'Histoire de la Population: Manuel de Dépouillement et d'Exploitation de l'Etat Civil Ancien, Paris: INED, 84 p.

Fleury M. and Valmary P. (1957). "Les Progrès de l'Instruction Elémentaire de Louis XIV à Napoléon III, Après l'Enquête de Louis Maggiolo (1877-1879)", Population, 12(1), pp. 71-92.

Fourastié, J. (1972). Les Trente Glorieuses. Paris : Editions Fayard.

Furet, F. and Ozouf, J. (1977). Lire et Ecrire : L'Alphabétisation des Français de Calvin à Jules Ferry. Paris: Minuit, 1977.

Ganiage J. (1963). "Trois Villages d'Ile-de-France au XVIIIe siècle. Étude Démographique. Présentation d'un Cahier de l'I.N.E.D.", Population, 18(1), pp. 129-132;

Gautier, E. and Henry, L. (1958). La Population de Crulai, Paroisse Normande. Paris: Presse Universitaire de France.

Galor, O. and O. Moav (2006), "Das Human-Kapital: A Theory of the Demise of the Class Structure," Review of Economic Studies, 73(1), pp. 85-117.

Galor, O. and Weil, D. N. (2000). "Population, Technology and Growth: From Malthusian Stagnation to the Demographic Transition and Beyond", American Economic Review, 90(4), pp. 806-828.

Galor, O. (2011). Unified Growth Theory. Princeton: Princeton University Press.

Greif, A. (1993). "Contract Enforceability and Economic Institutions in Early Trade: The Maghribi Traders' Coalition", American Economic Review, 83(3), pp. 525-48.

Greif, A. (2006). Institutions and the Path to the Modern Economy: Lessons from Medieval Trade. Cambridge: Cambridge University Press.

Hadeishi, H. (2003). "Economic Well-Being and Fertility in France: Nuits, 1744-1792", Journal of Economic History, 63(2), pp. 489-505.

Henry, L. (1972a). "La Fécondité des Mariages dans le Quart Sud-Ouest de la France de 1720 à 1829 (1)," Annales Economies Societés Civilisations, 27(3), pp. 612-639.

Henry, L. (1972b). "La Fécondité des Mariages dans le Quart Sud-Ouest de la France de 1720 à 1829 (2)", Annales Economies Societés Civilisations, 27(4-5), pp. 977-1023.

Henry, L. and J. Houdaille (1973). "La Fécondité des Mariages dans le Quart Nord-Ouest de la France 
de 1670 à 1829", Population, 28(4-5), pp. 873-924.

Henry, L. (1978). "La Fécondité des Mariages dans le Quart Sud-Est de la France de 1670 à 1829", Population, 33(4-5), pp. 855-883.

Houdaille, J. (1976). "La Fécondité des Mariages dans le quart Nord-Est de la France de 1670 à $1829 "$, Annales de Démographie Historique, 1976(1), pp. 341-392.

Jaurès, J. (1901). "La Révolution Française et le Droit Successoral", Études Socialistes 3(4), Paris: Cahiers de la Quinzaine, pp. 205-225.

Kalemli-Ozcan, S., Ryder, H. E. and Weil, D. N. (2000). "Mortality Decline, Human Capital Investment, and Economic Growth", Journal of Development Economics, 62(1), pp. 1-23.

Kalemli-Ozcan, S. (2003), "A Stochastic Model of Mortality, Fertility, and Human Capital Investment", Journal of Development Economics, 70 (1), pp. 103-118.

Knittel, F. (2004). "L'Enseignement Vétérinaire : Un Progrès pour le Monde Agricole (1761-1848). L'Exemple Lorrain", Cahiers Lorrains, 1, pp. 26-47.

Lanjouw, P. and N. Stern, N., eds. (1998). Economic Development in Palanpur over Five Decades. Oxford, UK: Oxford University Press.

Lévy-Leboyer, M. and F. Bourguignon (1985). L'Economie Française au XIXème Siecle: Analyse Macro-économique. Paris: Economica.

Lorentzen, P., J. McMillan and R. Wacziarg (2008), "Death and Development", Journal of Economic Growth, 13(2), pp. 81-124.

Marcadé, E. (1899). "Monographie Communale De Saint-Germain d'Anxure", monograph, August 2. Mokyr, J. (2005). "Long Term Economic Growth and the History of Technology", chapter 17 in P. Aghion and S. Durlauf, eds, Handbook of Economic Growth, vol. 1B.

Mokyr, J. (2000). "Knowledge, Technology, and Economic Growth during the Industrial Revolution," chapter 9 in in B. van Ark, S. K. Kuipers, G. H. Kuper, eds. Productivity, Technology and Economic Growth, New York: Springer US.

Morrisson, C. and W. Snyder (2000). The Income Inequality of France in Historical Perspective", European Review of Economic History, 4(1): pp. 59-83.

North, D. C. and B. R. Weingast (1989). "Constitutions and Commitment: The Evolution of Institutions Governing Public Choice in Seventeenth-Century England", Journal of Economic History, 49(4), pp. 803-832.

Palloni, A. and H. Rafalimanana (1999). "The Effects of Infant Mortality on Fertility Revisited: New Evidence from Latin America", Demography, 36(1), pp. 41-58.

Perret, J., M. Gribaudi, M. Barthelemy, N. Abadie, S. Baciocchi, C. Bertelli, O. Bonin, P. Bordin, B. Costes, P. Cristofoli, B. Dumenieu, J. Gravier, J. P. Hubert, P. A. Le Ny, E. Mermet, C. Motte, M. Pardoen, A. M. Raimond, S. Robert, M. C. Vouloir (2015), "The 18th Century Cassini Roads and Cities Dataset", https://doi.org/10.7910/DVN/28674, Harvard Dataverse, V5.

Pinker, Steven (2018), Enlightenment Now: The Case for Reason, Science, Humanism, and Progress, New York: Viking. 
Preston, S. (1978). The Effects of Infant and Child Mortality on Fertility, New York: Academic Press. Rozental, Alek A. (1956). "The Enclosure Movement in France", American Journal of Economics and Sociology, 16(1), pp. 55-71.

Smith, J. Harvey (1975). "Work Routine and Social Structure in a French Village: Cruzy in the Nineteenth Century", Journal of Interdisciplinary History, 5(3), pp. 357-382.

Spolaore, E. and Wacziarg, R. (2013). "How Deep Are the Roots of Economic Development?" Journal of Economic Literature, 51(2), pp. 325-69.

Spolaore, E. and Wacziarg, R. (2014). "Fertility and Modernity", working paper, UCLA and Tufts University.

Squicciarini, M. P. and N. Voigtländer. (2015). "Human Capital and Industrialization: Evidence from the Age of Enlightenment", Quarterly Journal of Economics, 130(4): pp. 1825-1883.

Squicciarini, M. P and N. Voigtländer. (2016). "Knowledge Elites and Modernization: Evidence from Revolutionary France", NBER Working Paper \#22779.

Statistiques Générales de la France (2011a). "Territoire et Population de 1800 à 1890", L'Atelier du Centre de Recherches Historiques, http://acrh.revues.org/3410; DOI: 10.4000/acrh.3410 (consulted on July 12, 2016).

Statistiques Générales de la France (2011b). "L'Enseignement Primaire de 1829 à 1897", L'Atelier du Centre de Recherches Historiques, http://journals.openedition.org/acrh/3376; DOI: 10.4000/acrh.3376 (consulted on January 14, 2019).

Vallin, J. (2006), "Europe's Demographic Transition, 1740-1940", Chapter 68 in Volume 3 of G. Caselli, J. Vallin and G. Wunsch (eds.), Demography: Analysis and Synthesis (4 Volume Set), Amsterdam: Academic Press (Elsevier).

Van De Walle, F. (1986), "Infant Mortality and the European Demographic Transition", Chapter 4 in A. J. Coale and S. C. Watkins, The Decline of Fertility in Europe, Princeton University Press, 1986. Voigtländer, N. and Voth, H.-J. (2013). "How the West "Invented" Fertility Restriction", American Economic Review, 103(6), pp. 2227-2264.

Weber, Eugen (1976), Peasants into Frenchmen: The Modernization of Rural France, 1870-1914, Stanford: Stanford University Press.

Weir, D. (1984). "Fertility Transition in Rural France, 1740-1829", Journal of Economic History, 44, pp. 612-614.

Wrigley, E. A. (1985). "The Fall of Marital Fertility in Nineteenth- Century France: Exemplar or Exception? (Parts I and II)", European Journal of Population, 1(1-3), pp. 31-60, 141-177. 


\section{TABLES AND FiguRES}

\begin{tabular}{|c|c|c|c|c|}
\hline $\begin{array}{l}\text { Class } \\
\text { Occupations }\end{array}$ & Professions & Freq. & $\begin{array}{l}\text { Class } \\
\text { score }\end{array}$ & $\begin{array}{l}\text { Skill } \\
\text { score }\end{array}$ \\
\hline \multicolumn{5}{|l|}{ Upper class } \\
\hline Bourgeois & $\begin{array}{l}\text { Doctor, landowner, mayor, notary, } \\
\text { rentier, merchant, large scale farmer } \\
\text { (métayer), teacher }\end{array}$ & $6.7 \%$ & 5.58 & 3.54 \\
\hline \multicolumn{5}{|l|}{ Upper-middle class } \\
\hline Skilled craftsmen & $\begin{array}{l}\text { Blacksmith, farrier, miller, veterinary } \\
\text { (hongreur, affranchisseur) }\end{array}$ & $5.7 \%$ & 2.99 & 1.78 \\
\hline \multicolumn{5}{|l|}{ Lower-middle class } \\
\hline Farmers & $\begin{array}{l}\text { Cultivator, peasant laborer, cropper } \\
\text { and sharecropper (closier) }\end{array}$ & $47.2 \%$ & 0.94 & 0.84 \\
\hline Textile workers & $\begin{array}{l}\text { Tailor (poupelier, calicotier, fileur), } \\
\text { shoemaker, weaver }\end{array}$ & $12.6 \%$ & 0.85 & 1.04 \\
\hline \multicolumn{5}{|l|}{ Lower class } \\
\hline Unskilled craftsmen & $\begin{array}{l}\text { Carpenter, clog-maker, joiner, mason, } \\
\text { roofer, stone mason, wheelwright, } \\
\text { worker }\end{array}$ & $8.3 \%$ & 0.32 & 0.57 \\
\hline Day laborers & $\begin{array}{l}\text { Day laborer, servant, woodcutter, mole } \\
\text { catcher }\end{array}$ & $17.2 \%$ & 0.15 & 0.17 \\
\hline \multicolumn{5}{|l|}{ Others } \\
\hline Services & $\begin{array}{l}\text { Innkeeper, administrative agent, cart } \\
\text { driver, butcher, baker, grocer, } \\
\text { postman, bartender, waiter }\end{array}$ & $2.3 \%$ & . & . \\
\hline
\end{tabular}

Table 3.1.4.1 - Occupational and Social Class Categories

Note: This table summarizes our categorization of professions into occupations and occupations into class. Table A3.1.4.1 and Table A3.1.4.2 describe the construction of the class and skill scores. There are 898 observations pertaining to the period after 1780 .

Source: Households Database 


\begin{tabular}{ccc}
\hline \hline & Fertility & Net fertility \\
& Mean/St.err./Obs & Mean/St.err./Obs \\
\hline $1740-1789$ & 3.29 & 2.43 \\
& $(0.15)[361]$ & $(0.12)[361]$ \\
$1790-1840$ & 2.42 & 2.03 \\
& $(0.14)[305]$ & $(0.12)[305]$ \\
$1841-1885$ & 2.18 & 1.90 \\
& $(0.14)[228]$ & $(0.13)[228]$ \\
\hline \hline
\end{tabular}

(Panel A) Fertility and net fertility

\begin{tabular}{cccc}
\hline \hline & Illiterate & Literate & Total \\
& Mean/St.err./Obs & Mean/St.err./Obs & Mean/St.err./Obs \\
\hline $1745-1789$ & 3.10 & 3.77 & 3.25 \\
& $(0.17)[255]$ & $(0.41)[69]$ & $(0.16)[324]$ \\
$1790-1840$ & 2.10 & 3.38 & 2.42 \\
& $(0.14)[236]$ & $(0.37)[69]$ & $(0.14)[305]$ \\
$1841-1880$ & 2.11 & 2.10 & 2.10 \\
& $(0.22)[70]$ & $(0.20)[123]$ & $(0.15)[193]$ \\
\hline \hline
\end{tabular}

(Panel B) Fertility, by literacy status

Table 4.1.1.1 - Fertility

Note: Panel A displays fertility and net fertility by period. Panel B displays fertility by literacy status and period. Fertility is defined as the total number of births per couple. Net fertility is defined as the average number of children per couple, net of those who died within their first four years. Observations are weighed by final migration score $B$ and only households with a migration score higher than $50 \%$ are retained (see Appendix A.1.2 for the construction of the migration score). The variable is coded as of the year of marriage (if available) or the year of birth of the first child. The dataset is truncated to observations between 1740 and 1885 in Panel A (so as to track all births for each couple) and between 1750 and 1870 in Panel B (because of too few literate observations at the beginning of our sample period and too few illiterates at the end). There are 894 observations in Panel A and 822 in Panel B.

Source: Households Database 


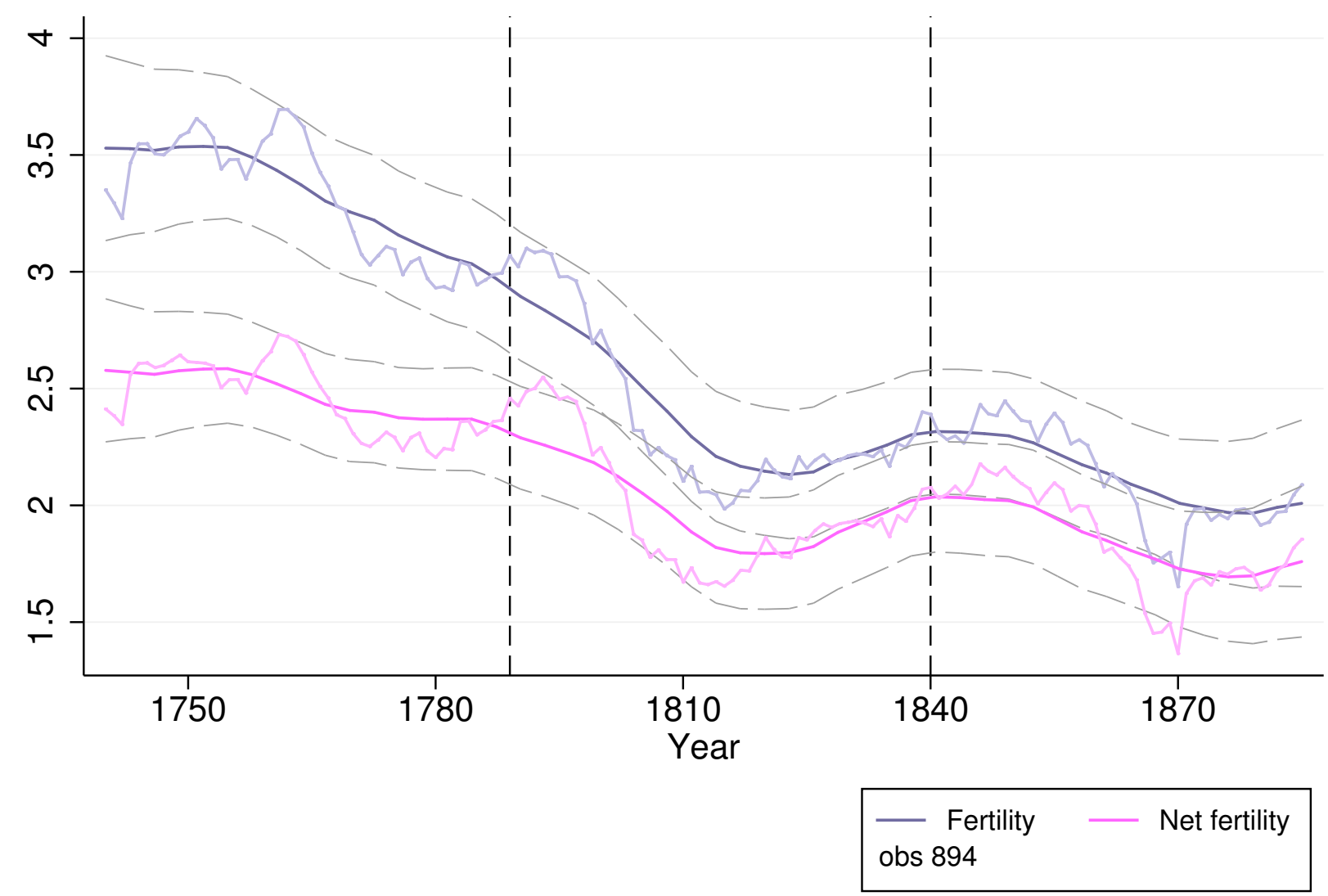

Note: Local polynomial of degree 0 and rolling average ; Epanechnikov kernel ; bandwidth $10 ; 90 \% \mathrm{Cl}$

Figure 4.1.1.1 - Fertility

Note: Fertility is defined as the total number of births per couple. Net fertility is defined as the average number of children per couple, net of those who died within their first four years. Observations are weighed by final migration score $B$ and only households with a migration score higher than $50 \%$ are retained (see Appendix A.1.2 for the construction of the migration score). The variable is coded as of the year of marriage (if available) or the year of birth of the first child. The dataset is truncated to observations between 1740 and 1885 so as to track all births for each couple. There are 894 observations.

Source: Households Database 


\begin{tabular}{|c|c|c|c|c|c|c|c|}
\hline & $(1)$ & $(2)$ & $(3)$ & $(4)$ & $(5)$ & $(6)$ & $(7)$ \\
\hline 1790-1840 dummy & $\begin{array}{c}-0.865^{* * *} \\
(0.218)\end{array}$ & $\begin{array}{c}-0.881^{* * *} \\
(0.215)\end{array}$ & $\begin{array}{c}-0.886^{* * *} \\
(0.215)\end{array}$ & $\begin{array}{c}-1.739^{* * *} \\
(0.349)\end{array}$ & $\begin{array}{c}-1.475^{* * *} \\
(0.346)\end{array}$ & $\begin{array}{c}-1.092^{* * *} \\
(0.388)\end{array}$ & $\begin{array}{c}-1.128^{* *} \\
(0.516)\end{array}$ \\
\hline 1841-1895 dummy & $\begin{array}{c}-1.110^{* * *} \\
(0.218)\end{array}$ & $\begin{array}{c}-1.438^{* * *} \\
(0.247)\end{array}$ & $\begin{array}{c}-0.999^{* * *} \\
(0.270)\end{array}$ & $\begin{array}{c}-1.508^{* * *} \\
(0.454)\end{array}$ & $\begin{array}{c}-1.569^{* * *} \\
(0.391)\end{array}$ & $\begin{array}{c}-0.766 \\
(0.516)\end{array}$ & $\begin{array}{c}-0.413 \\
(0.701)\end{array}$ \\
\hline Literacy & & $\begin{array}{c}0.691^{* * *} \\
(0.229)\end{array}$ & $\begin{array}{c}0.901^{* * *} \\
(0.296)\end{array}$ & $\begin{array}{c}1.131^{* * *} \\
(0.410)\end{array}$ & $\begin{array}{c}1.110^{* * *} \\
(0.376)\end{array}$ & $\begin{array}{c}1.146^{* * *} \\
(0.374)\end{array}$ & $\begin{array}{c}1.732^{* * *} \\
(0.477)\end{array}$ \\
\hline Literacy $\times 1841-1895$ & & & $\begin{array}{c}-0.763^{*} \\
(0.411)\end{array}$ & $\begin{array}{c}-2.155^{* * *} \\
(0.579)\end{array}$ & $\begin{array}{c}-1.232^{* * *} \\
(0.473)\end{array}$ & $\begin{array}{c}-1.317^{* * *} \\
(0.475)\end{array}$ & $\begin{array}{c}-2.839^{* * *} \\
(0.642)\end{array}$ \\
\hline Mother's marriage age (standardized) & & & & $\begin{array}{c}-0.516^{* * *} \\
(0.146)\end{array}$ & & & $\begin{array}{c}-0.363^{* *} \\
(0.169)\end{array}$ \\
\hline Father's marriage age (standardized) & & & & $\begin{array}{c}-0.201 \\
(0.176)\end{array}$ & & & $\begin{array}{c}-0.200 \\
(0.170)\end{array}$ \\
\hline Lower-middle class dummy & & & & & $\begin{array}{c}0.771^{* * *} \\
(0.222)\end{array}$ & $\begin{array}{c}0.760^{* * *} \\
(0.224)\end{array}$ & $\begin{array}{l}0.656^{*} \\
(0.336)\end{array}$ \\
\hline Upper-middle class dummy & & & & & $\begin{array}{c}0.758 \\
(0.484)\end{array}$ & $\begin{array}{c}0.676 \\
(0.473)\end{array}$ & $\begin{array}{c}0.109 \\
(0.605)\end{array}$ \\
\hline Upper class dummy & & & & & $\begin{array}{l}0.943^{*} \\
(0.500)\end{array}$ & $\begin{array}{c}0.906^{*} \\
(0.505)\end{array}$ & $\begin{array}{c}0.583 \\
(0.640)\end{array}$ \\
\hline Ambient child mortality (standardized) & & & & & & $\begin{array}{c}0.383^{* *} \\
(0.152)\end{array}$ & $\begin{array}{c}0.453^{* *} \\
(0.196)\end{array}$ \\
\hline Constant & $\begin{array}{c}3.289^{* * *} \\
(0.160)\end{array}$ & $\begin{array}{c}3.130^{* * *} \\
(0.162)\end{array}$ & $\begin{array}{c}3.081^{* * *} \\
(0.165)\end{array}$ & $\begin{array}{c}3.815^{* * *} \\
(0.294)\end{array}$ & $\begin{array}{c}3.245^{* * *} \\
(0.341)\end{array}$ & $\begin{array}{c}2.880^{* * *} \\
(0.381)\end{array}$ & $\begin{array}{c}2.785^{* * *} \\
(0.507)\end{array}$ \\
\hline Observations & 894 & 894 & 894 & 410 & 592 & 592 & 318 \\
\hline$R^{2}$ & 0.03 & 0.05 & 0.05 & 0.23 & 0.13 & 0.14 & 0.28 \\
\hline
\end{tabular}

Table 4.1.2.1 - Fertility regressions

Note: This table displays weighed regressions for household fertility. Robust standard errors are reported in parentheses. Main specification is column (6). Fertility is defined as the total number of births per couple. Observations are weighed by migration score B and only households with a migration score higher than 50\% are retained (see Appendix A.1.2 for the construction of the migration score). To capture all births, we retain only years between 1740 and 1885. Ambient child mortality is defined as the average child mortality in the years minus 5 to minus 15 . It is standardized to have mean 0 and standard deviation 1.

Source: Households Database 


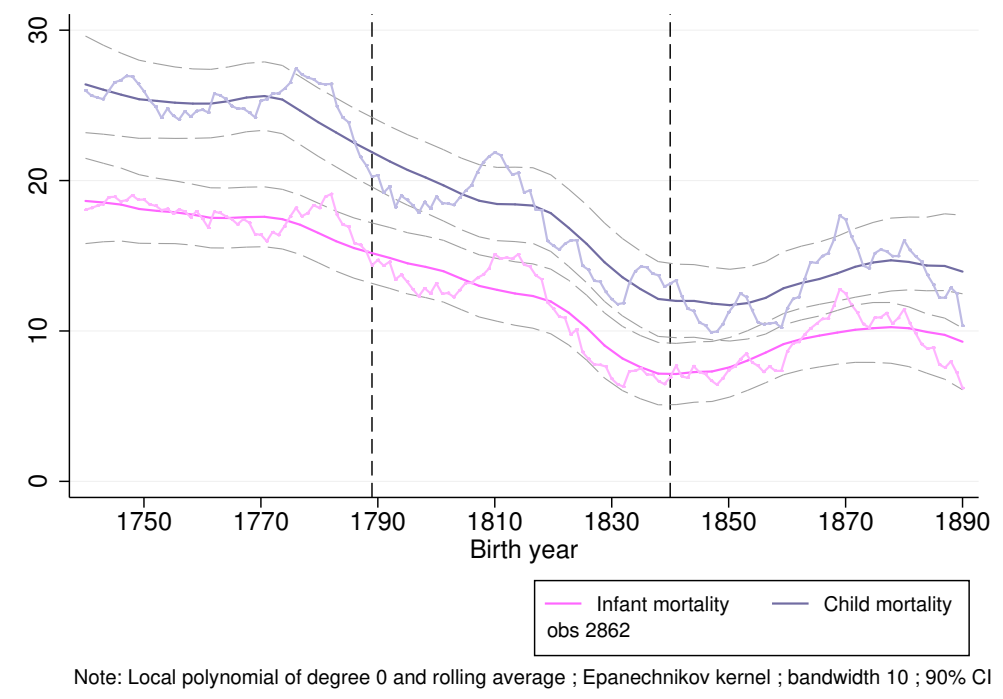

(Panel A) Infant and child mortality

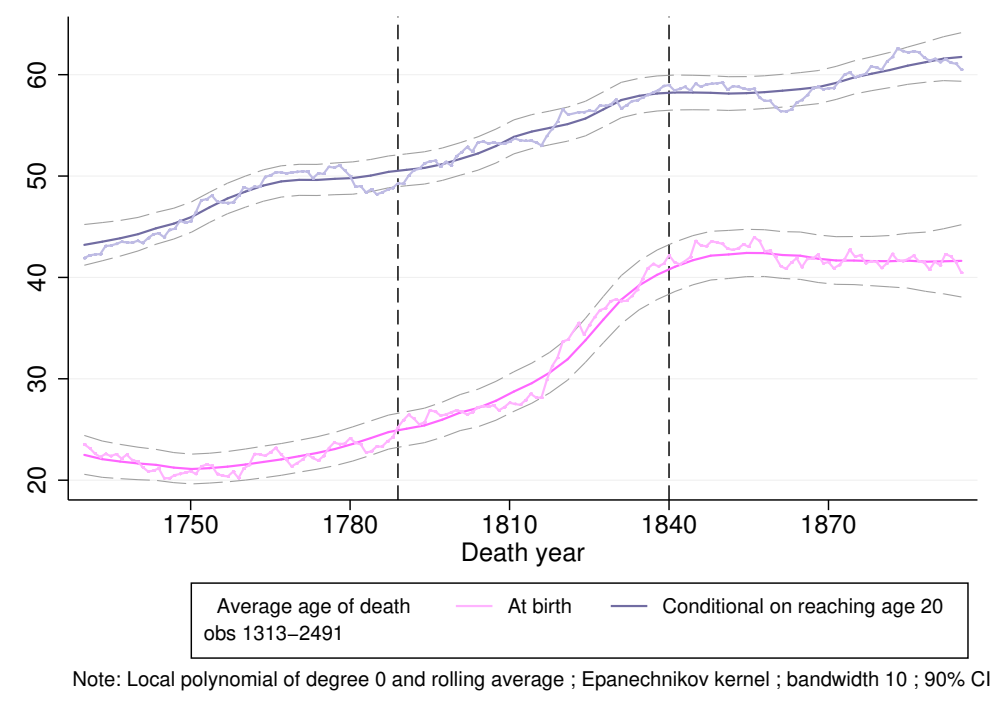

(Panel B) Life expectancy

Figure 4.2.1.1 - Mortality

Note: Panel A displays infant and child mortality over time. Infant mortality is defined as the percentage of children dying before the age of one and child mortality the percentage dying within the first four years of their life. For each birth, we track any death record following within the next 1 or 4 years and conclude that the child survived if there was no death record. The variable is coded as of the year of birth. The figure is truncated due to poor data before 1740 (first names poorly recorded). There are 2862 observations.

Panel B displays life expectancy at birth and at age of 20 over time. Life expectancy is defined as the average age of death. There are 1313 observations for life expectancy at 20 and 2491 for life expectancy at birth.

Sources : Households Database (Panel A) and Deaths Database (Panel B) 


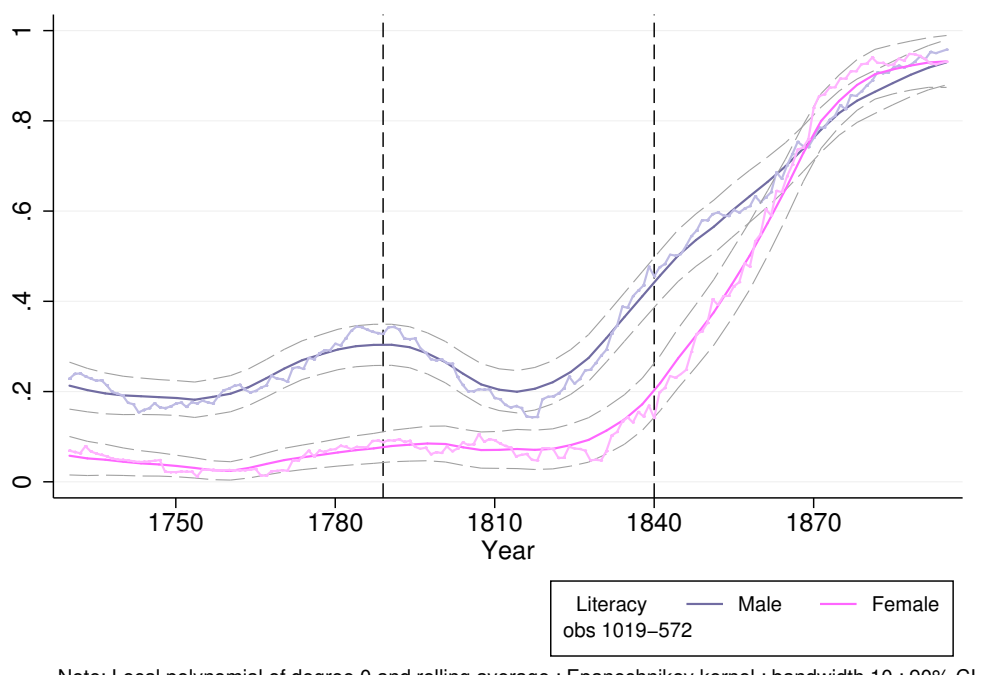

(Panel A) By gender

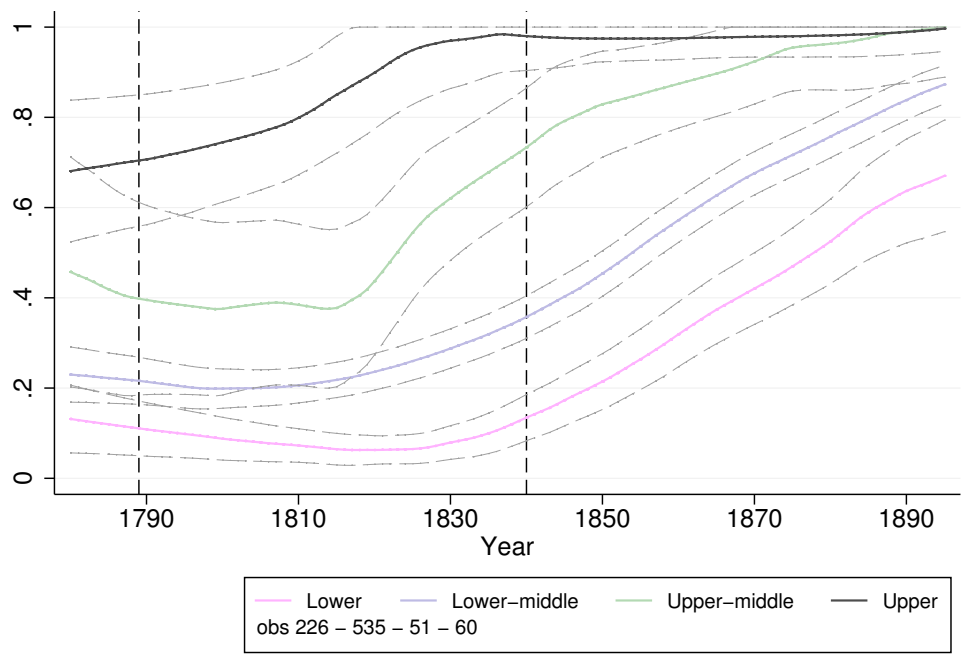

Note: Local polynomial of degree 0 ; Epanechnikov kernel ; bandwidth $15 ; 90 \% \mathrm{Cl}$

(Panel B) By class

Figure 5.1.0.1 - Literacy

Note: Panel A displays the rate of literacy by gender, Panel B displays the rate of literacy by class. Literacy is defined as in Section 3. The variable is coded as of the year of marriage (if available) or the year of birth of the first child. Observations are weighed by final migration score $B$ (see Appendix A.1.2 for the construction of the migration score). In Panel A, only households with a migration score higher than 50\% are retained: there are 1019 observations for males and 572 for females. In Panel B, we use men's literacy and there are 894 observations: 226 lower class, 535 lower-middle class, 51 upper-middle class and 60 upper class. Occupations were poorly reported before 1780, so the figure only displays data post 1780 .

Source: Households Database 


\begin{tabular}{lccc}
\hline \hline Literacy $\mathrm{t} \downarrow \mid \mathrm{t}-1 \rightarrow$ & 0 & 1 & Total \\
\hline 0 & 71.10 & 27.59 & 60.24 \\
& $(310)$ & $(40)$ & $(350)$ \\
1 & 28.90 & 72.41 & 39.76 \\
& $(126)$ & $(105)$ & $(231)$ \\
Total & 100.00 & 100.00 & 100.00 \\
& $(436)$ & $(145)$ & $(581)$ \\
\hline \hline
\end{tabular}

(Panel A) Whole sample (1730 - 1895)

\begin{tabular}{lccc}
\hline \hline Literacy $\mathrm{t} \downarrow \mid \mathrm{t}-1 \rightarrow$ & 0 & 1 & Total \\
\hline 0 & 84.76 & 43.18 & 75.96 \\
& $(139)$ & $(19)$ & $(158)$ \\
1 & 15.24 & 56.82 & 24.04 \\
& $(25)$ & $(25)$ & $(50)$ \\
Total & 100.00 & 100.00 & 100.00 \\
& $(164)$ & $(44)$ & $(208)$ \\
\hline \hline
\end{tabular}

(Panel C) $1790-1840$

\begin{tabular}{lccc}
\hline \hline Literacy $\mathrm{t} \downarrow \mid \mathrm{t}-1 \rightarrow$ & 0 & 1 & Total \\
\hline 0 & 81.76 & 40.00 & 72.87 \\
& $(121)$ & $(16)$ & $(137)$ \\
1 & 18.24 & 60.00 & 27.13 \\
& $(27)$ & $(24)$ & $(51)$ \\
Total & 100.00 & 100.00 & 100.00 \\
& $(148)$ & $(40)$ & $(188)$ \\
\hline \hline
\end{tabular}

(Panel B) $1730-1789$

\begin{tabular}{|c|c|c|c|c|}
\hline Literacy t $\downarrow$ & $\mathrm{t}-1 \rightarrow$ & 0 & 1 & Total \\
\hline 0 & & $\begin{array}{c}40.32 \\
(50)\end{array}$ & $\begin{array}{c}8.20 \\
(5)\end{array}$ & $\begin{array}{c}29.73 \\
(55)\end{array}$ \\
\hline 1 & & $\begin{array}{c}59.68 \\
(74)\end{array}$ & $\begin{array}{c}91.80 \\
(56)\end{array}$ & $\begin{array}{l}70.27 \\
(130)\end{array}$ \\
\hline Total & & $\begin{array}{c}100.00 \\
(124)\end{array}$ & $\begin{array}{c}100.00 \\
(61)\end{array}$ & $\begin{array}{c}100.00 \\
(185)\end{array}$ \\
\hline
\end{tabular}

(Panel D) $1841-1895$

Table 5.2.0.1 - Transition matrix for literacy, by period

Note: This table displays the literacy status of the son conditional on the father's literacy status. For example, in Panel A, first row, second column reads: overall, $27.59 \%$ of those with a literate father are illiterate. Literacy is defined as in Section 3. We use men's literacy. Panel A displays the transition matrix for the whole period. In Panels B, C and D we break down the sample by period. The variable is coded as of the year of marriage (if available) or the year of birth of the first child.

Source: Households Database 


\begin{tabular}{|c|c|c|c|c|c|}
\hline & (1) & $(2)$ & $(3)$ & $(4)$ & $(5)$ \\
\hline Father's literacy (t-1) & $\begin{array}{c}0.435^{* * *} \\
(0.043)\end{array}$ & $\begin{array}{c}0.421^{* * *} \\
(0.050)\end{array}$ & $\begin{array}{c}0.270^{* * *} \\
(0.077)\end{array}$ & $\begin{array}{c}0.295^{* * *} \\
(0.078)\end{array}$ & $\begin{array}{c}0.291^{* * *} \\
(0.043)\end{array}$ \\
\hline 1790-1840 dummy & & $\begin{array}{c}-0.027 \\
(0.036)\end{array}$ & $\begin{array}{l}-0.040 \\
(0.028)\end{array}$ & $\begin{array}{l}-0.065 \\
(0.042)\end{array}$ & $\begin{array}{l}-0.022 \\
(0.019)\end{array}$ \\
\hline 1841-1895 dummy & & $\begin{array}{c}0.413^{* * *} \\
(0.048)\end{array}$ & $\begin{array}{c}0.276^{* * *} \\
(0.056)\end{array}$ & $\begin{array}{l}0.185^{* *} \\
(0.092)\end{array}$ & $\begin{array}{c}0.249^{* * *} \\
(0.059)\end{array}$ \\
\hline Lower-middle class dummy (t) & & & $\begin{array}{c}0.183^{* * *} \\
(0.046)\end{array}$ & $\begin{array}{c}0.216^{* * *} \\
(0.059)\end{array}$ & \\
\hline Upper-middle class dummy (t) & & & $\begin{array}{l}0.322^{* *} \\
(0.129)\end{array}$ & $\begin{array}{c}0.378^{* * *} \\
(0.138)\end{array}$ & \\
\hline Upper class dummy (t) & & & $\begin{array}{c}0.639^{* * *} \\
(0.117)\end{array}$ & $\begin{array}{c}0.688^{* * *} \\
(0.108)\end{array}$ & \\
\hline Life expectancy at 20 & & & & $\begin{array}{c}0.008 \\
(0.007)\end{array}$ & $\begin{array}{l}0.006^{*} \\
(0.003)\end{array}$ \\
\hline Male dummy & & & & & $\begin{array}{c}0.137^{* * *} \\
(0.028)\end{array}$ \\
\hline Observations & 581 & 581 & 436 & 431 & 1027 \\
\hline Pseudo R-squared & .11 & .24 & .29 & .29 & .32 \\
\hline
\end{tabular}

Table 5.3.0.1 - Literacy regressions

Note: The dependent variable is literacy status. We use men's literacy in columns (1) to (4), and all genders in column (5) (in this column we omit class dummies since theyr are not coded for females before Period III). All specifications are probit regressions and we report marginal effects (at the mean for non-categorical variables). Robust standard errors are reported in parentheses. Main specification is column (4). Literacy is defined as in Section 3. The dataset is truncated to observations after 1735 in column (4) and (5) to allow for an estimation of life expectancy. Life expectancy at 20 is the average death age of adults (more than 20 years old) in the 15 years before the coded year of observation of the household.

Source: Households Database 


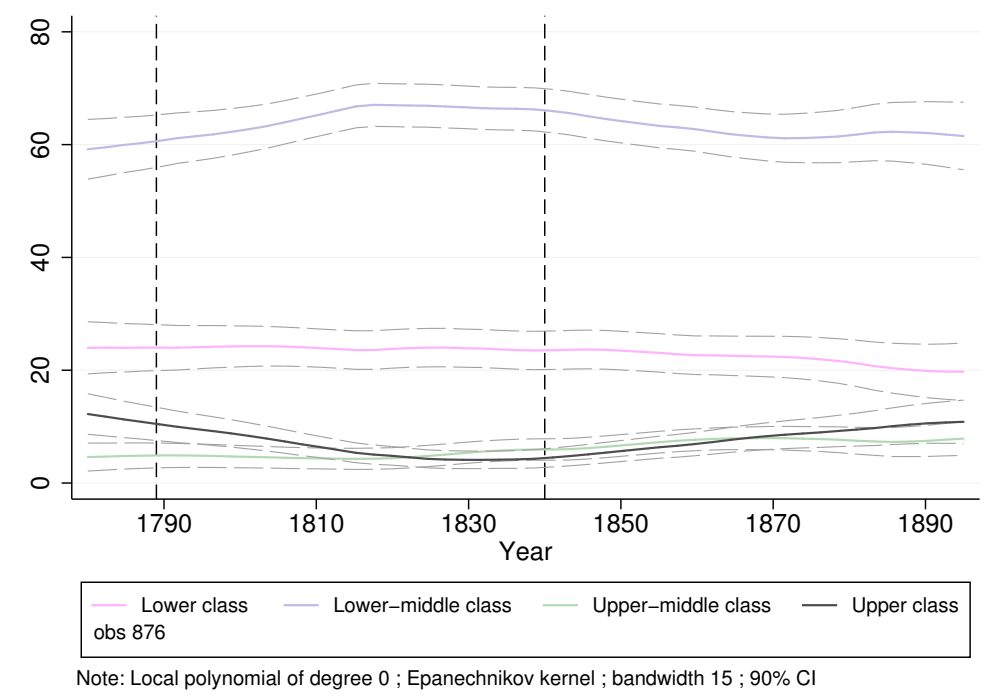

(Panel A) Male

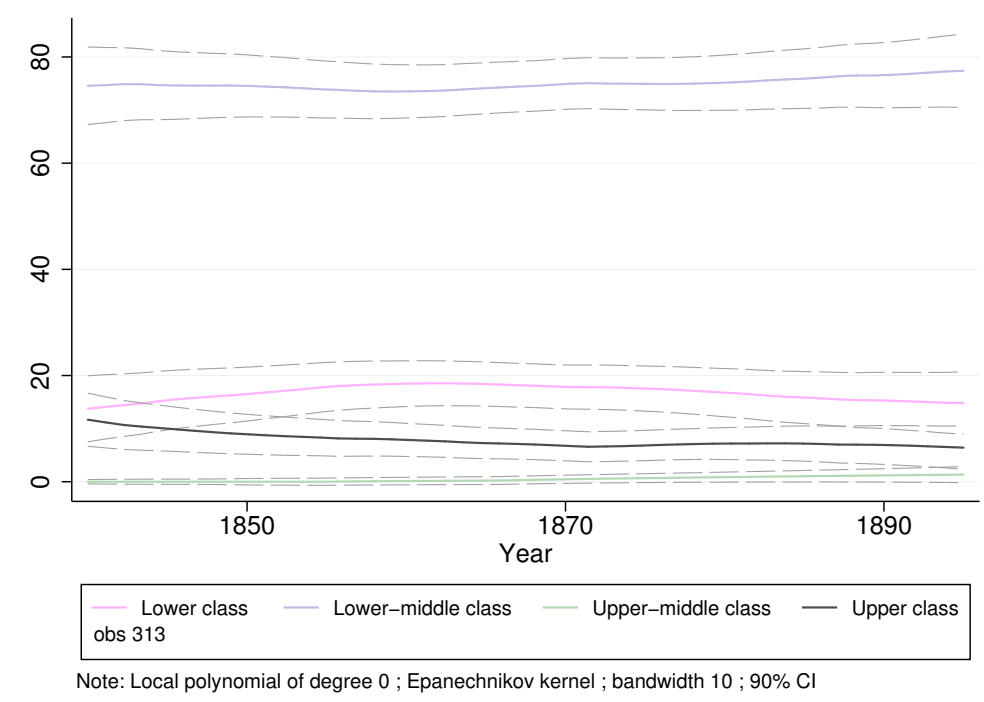

(Panel B) Female

Figure 6.1.0.1 - Class structure over time

Note: Figure A (B) displays the time evolution of the average percentage of males (females) by class. Year of observation is the year of marriage or of first child. Observations are weighed by final migration score $B$ (see Appendix A.1.2 for the construction of the migration score). There are 876 observations in Panel A and 313 in Panel B. Panels A and B are truncated due to poor data, before 1780 for Panel A and before 1840 for Panel B: occupations not recorded.

Source: Households Database 


\begin{tabular}{lccccc}
\hline \hline Class in $\mathrm{t} \downarrow \mid \mathrm{t}-1 \rightarrow$ & $\mathrm{a}$ & $\mathrm{b}$ & $\mathrm{c}$ & $\mathrm{d}$ & Total \\
\hline a- Lower & 52.46 & 15.64 & 0.00 & 6.06 & 20.94 \\
& $(32)$ & $(33)$ & $(0)$ & $(2)$ & $(67)$ \\
b- Lower-middle & 42.62 & 81.04 & 20.00 & 39.39 & 66.56 \\
& $(26)$ & $(171)$ & $(3)$ & $(13)$ & $(213)$ \\
c- Upper-middle & 1.64 & 1.42 & 80.00 & 0.00 & 5.00 \\
& $(1)$ & $(3)$ & $(12)$ & $(0)$ & $(16)$ \\
d- Upper & 3.28 & 1.90 & 0.00 & 54.55 & 7.50 \\
& $(2)$ & $(4)$ & $(0)$ & $(18)$ & $(24)$ \\
Total & 100.00 & 100.00 & 100.00 & 100.00 & 100.00 \\
& $(61)$ & $(211)$ & $(15)$ & $(33)$ & $(320)$ \\
\hline \hline
\end{tabular}

(Panel A) Whole sample $(1780-1895)$

\begin{tabular}{lccccc}
\hline \hline Class in $\mathrm{t} \downarrow \mid \mathrm{t}-1 \rightarrow$ & $\mathrm{a}$ & $\mathrm{b}$ & $\mathrm{c}$ & $\mathrm{d}$ & Total \\
\hline a- Lower & 64.29 & 12.24 & 0.00 & 0.00 & 16.67 \\
& $(9)$ & $(12)$ & $(0)$ & $(0)$ & $(21)$ \\
b- Lower-middle & 21.43 & 85.71 & 40.00 & 55.56 & 74.60 \\
& $(3)$ & $(84)$ & $(2)$ & $(5)$ & $(94)$ \\
c- Upper-middle & 7.14 & 1.02 & 60.00 & 0.00 & 3.97 \\
& $(1)$ & $(1)$ & $(3)$ & $(0)$ & $(5)$ \\
d- Upper & 7.14 & 1.02 & 0.00 & 44.44 & 4.76 \\
& $(1)$ & $(1)$ & $(0)$ & $(4)$ & $(6)$ \\
Total & 100.00 & 100.00 & 100.00 & 100.00 & 100.00 \\
& $(14)$ & $(98)$ & $(5)$ & $(9)$ & $(126)$ \\
\hline \hline
\end{tabular}

(Panel B) $1790-1840$

\begin{tabular}{lccccc}
\hline \hline Class in $\mathrm{t} \downarrow \mid \mathrm{t}-1 \rightarrow$ & $\mathrm{a}$ & $\mathrm{b}$ & $\mathrm{c}$ & $\mathrm{d}$ & Total \\
\hline a- Lower & 43.90 & 18.28 & 0.00 & 13.33 & 23.42 \\
& $(18)$ & $(17)$ & $(0)$ & $(2)$ & $(37)$ \\
b- Lower-middle & 53.66 & 77.42 & 11.11 & 40.00 & 63.92 \\
& $(22)$ & $(72)$ & $(1)$ & $(6)$ & $(101)$ \\
c- Upper-middle & 0.00 & 1.08 & 88.89 & 0.00 & 5.70 \\
& $(0)$ & $(1)$ & $(8)$ & $(0)$ & $(9)$ \\
d- Upper & 2.44 & 3.23 & 0.00 & 46.67 & 6.96 \\
& $(1)$ & $(3)$ & $(0)$ & $(7)$ & $(11)$ \\
Total & 100.00 & 100.00 & 100.00 & 100.00 & 100.00 \\
& $(41)$ & $(93)$ & $(9)$ & $(15)$ & $(158)$ \\
\hline \hline
\end{tabular}

(Panel C) $1841-1895$

Table 6.2.0.1 - Transition matrix for social class

Note: This table displays the class of the father in columns and the class of his son in rows. Occupations are defined in Section 3.1.4. We only use males' occupations, after 1780 (Panel A). In Panels B and C, we break down the sample into two periods. The variable is coded as of the year of marriage (if available) or the year of birth of the first child. We de not display the matrix for Period I because of poor data before 1780 (occupations not recorded).

Source: Households Database 


\begin{tabular}{|c|c|c|c|c|c|c|}
\hline & (1) & (2) & (3) & (4) & (5) & (6) \\
\hline Father's class rank (t-1) & $\begin{array}{c}0.494^{* * *} \\
(0.069)\end{array}$ & $\begin{array}{c}0.454^{* * *} \\
(0.071)\end{array}$ & $\begin{array}{c}0.393^{* * *} \\
(0.076)\end{array}$ & $\begin{array}{c}0.390^{* * *} \\
(0.125)\end{array}$ & $\begin{array}{c}0.438^{* * *} \\
(0.066)\end{array}$ & $\begin{array}{c}0.433^{* * *} \\
(0.068)\end{array}$ \\
\hline Literacy (t) & & $\begin{array}{c}0.225^{* * *} \\
(0.080)\end{array}$ & $\begin{array}{c}0.279^{* * *} \\
(0.081)\end{array}$ & $\begin{array}{c}0.279^{* * *} \\
(0.080)\end{array}$ & $\begin{array}{c}0.254^{* * *} \\
(0.073)\end{array}$ & $\begin{array}{c}0.252^{* * *} \\
(0.073)\end{array}$ \\
\hline Class rank $(\mathrm{t}-1) \times$ Period III & & & & $\begin{array}{c}0.004 \\
(0.153)\end{array}$ & & \\
\hline Gender dummy ( $1=$ female $)$ & & & & & $\begin{array}{l}-0.067 \\
(0.100)\end{array}$ & \\
\hline Class rank $(\mathrm{t}-1) \times$ Gender dummy & & & & & & $\begin{array}{c}-0.002 \\
(0.053)\end{array}$ \\
\hline Sample includes daughters & No & No & No & No & Yes & Yes \\
\hline Period I excluded & No & No & Yes & Yes & Yes & Yes \\
\hline Observations & 312 & 312 & 284 & 284 & 352 & 352 \\
\hline $\mathrm{R}^{2}$ & 0.29 & 0.31 & 0.26 & 0.26 & 0.29 & 0.29 \\
\hline
\end{tabular}

Table 6.3.0.1 - Regression analysis of intergenerational class mobility

Note: This table displays regressions explaining intergenerational class mobility. t-statistics are reported in parentheses. The dependent variable is class rank for generation $t$. The explanatory variable class rank in $t-1$ is the class rank of the father. Class rank is 1 for the lower class, 2 for the lower-middle class, 3 for the upper-middle class and 4 for the upper class. All specifications include period dummies. In all specifications, we drop observations before 1780 due to poor data quality (occupations not recorded).

Source: Households Database 


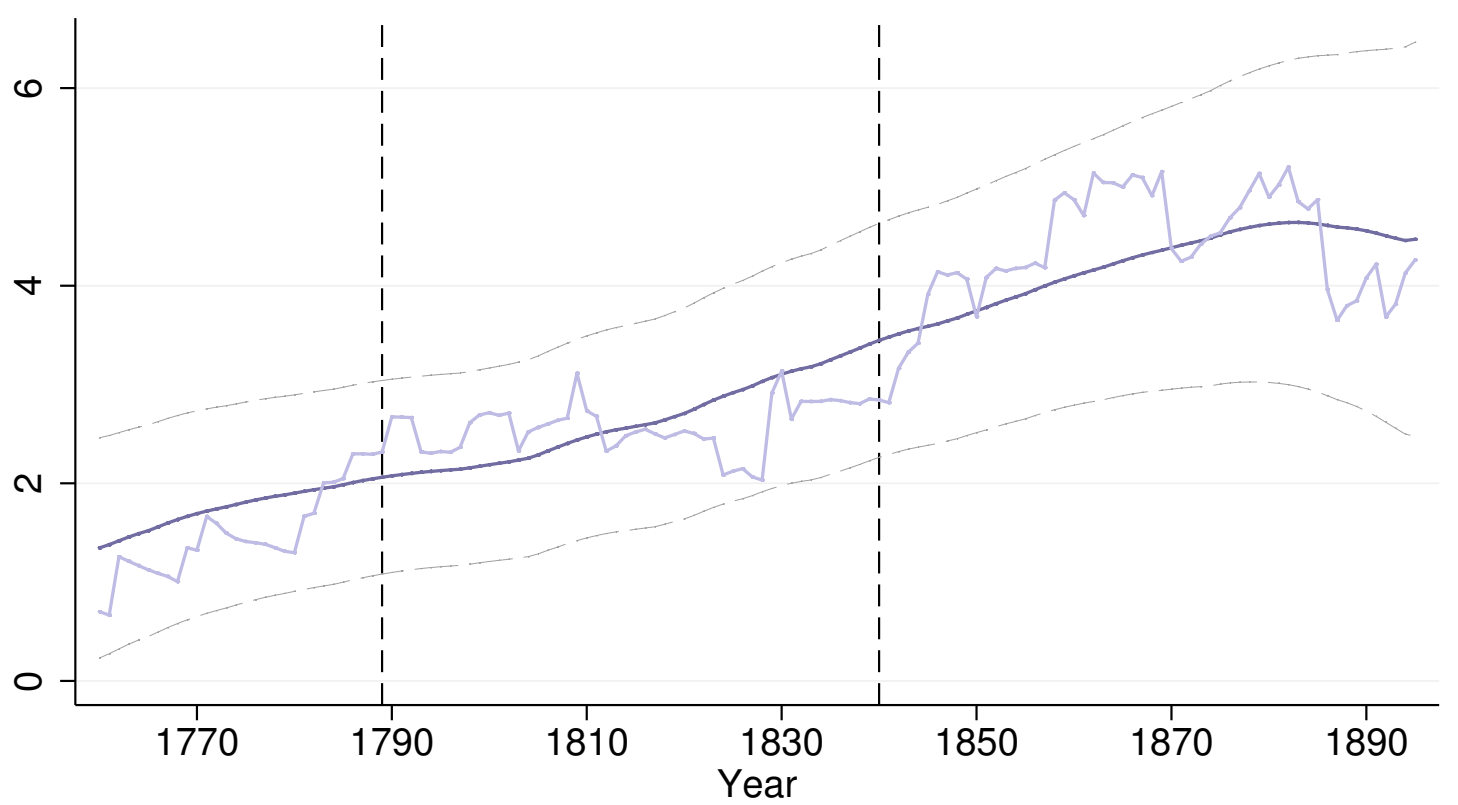

- Share landowners obs $1213 ; 3$ landowners in Period I, 20 in Period III

Note: Local polynomial of degree 0 and rolling average ; Epanechnikov kernel ; bandwidth 20 ; $90 \% \mathrm{Cl}$

Figure 6.4.0.1 - Landowners

Note: This figure displays the percentage of recorded landowners, out of the total number of households in a given window. Observations are weighed by final migration score $B$ (see Appendix A.1.2 for the construction of the migration score). The variable is coded as of the year of marriage (if available) or the year of birth of the first child. There are 1213 observations. The figure is truncated due to poor data before 1760 (land ownership not recorded).

Source: Households Database 


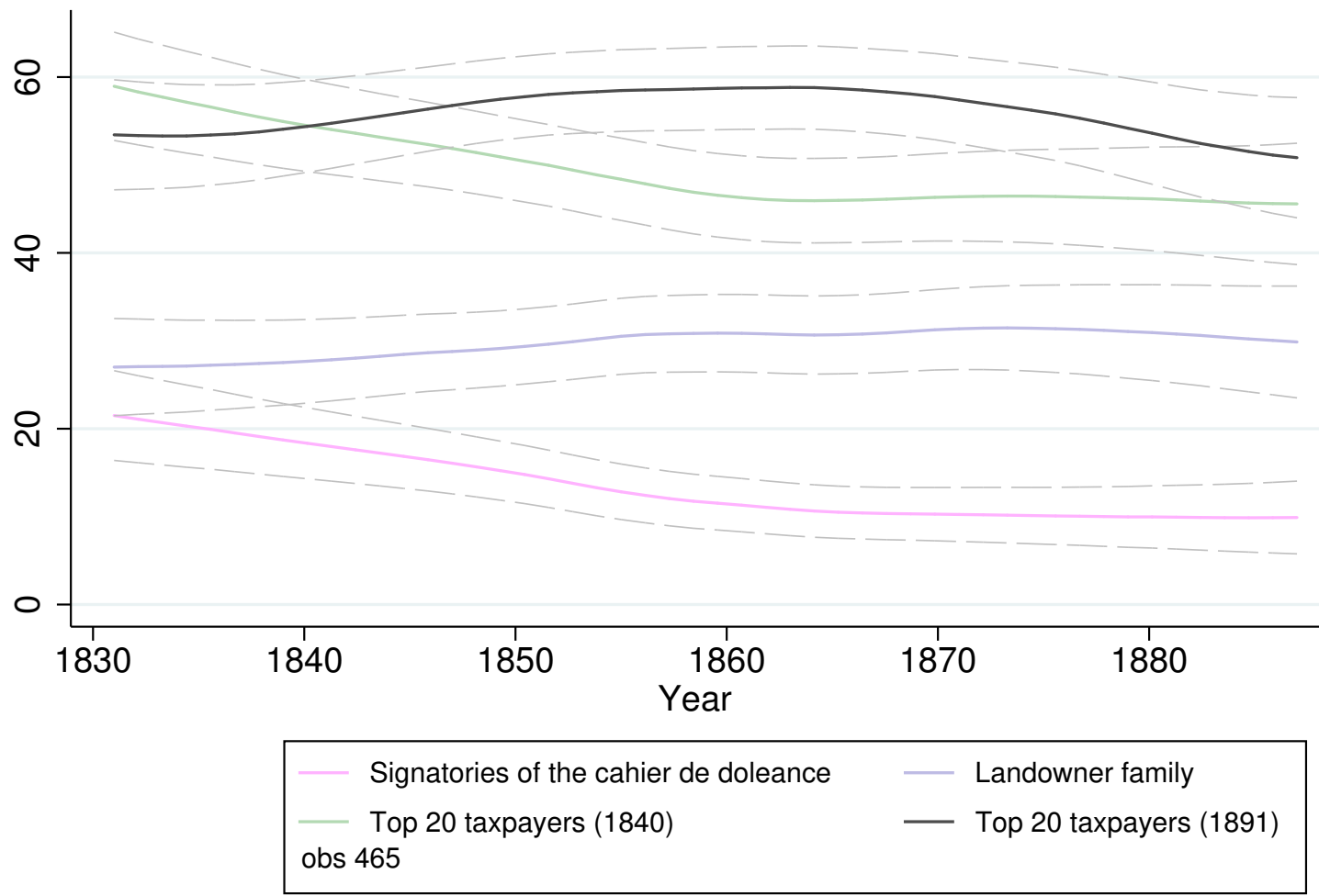

Note: Local polynomial of degree 0 ; Epanechnikov kernel ; bandwidth 10 ; $90 \% \mathrm{Cl}$

Figure 6.4.0.2 - Surname analysis of the municipal council

Note: This figure displays (as local polynomials with $90 \%$ confidence intervals) the percentage of names appearing in the municipal council (always less than 10 members) that also are socially and economically prestigious name in SGA. We use signatories of the cahier de doléance (1789), landowner family, top 20 taxpayers (1840) and top 20 taxpayers (1891). A family name is coded as landowner if at least one person with that family name was coded as landowner in the households database. Top 20 taxpayers is defined in 1840 from the municipal cens, the aggregate amount of taxes paid by individuals (used to define voting rights), which includes mostly the property tax (Tudesq 1958). The variable is defined in 1890 using the data on property tax only. In the households database, $6 \%$ of individuals share the same last name as one of the signatories of the cahier de doléance, about $2 \%$ of individuals are landowners and $11 \%$ share the same last name as someone recorded as landowner, about 15-20\% share the same last name as one of the top 20 taxpayers in 1840 and 1891.

Sources : Households Database \& Public Budget 


\section{Interval date of transition}

\section{Life expectancy at $\mathbf{2 0}$}

First sustained 10\% increase

First sustained 25\% increase

Child mortality rate

First sustained 10\% decrease

First sustained 25\% decrease

Fertility \& net fertility

First sustained 10\% decrease

First sustained 25\% decrease

\section{Literacy rate}

First sustained $75 \%$ increase

First sustained $150 \%$ increase

\section{Class immobility}

First sustained 10\% change

First sustained 25\% change
$[1742,1751]$

not in sample

[1783, 1792]

$[1813,1822]$

$[1794,1803]$

[1797, 1806]

[1829, 1838]

[1841, 1850]

not in sample

not in sample

Table 7.1.0.1 - Estimated years of transition

Note: This table presents estimated periods of first sustained increase or decrease for a set of variables of interest. For any date $t$, we define $Y\left(B_{t}\right)$ as the average value of variable $y$ during the 10 years before $t$ (excluding $t$ ) and $Y\left(A_{t}\right)$ its average value during the 10 years after $t$ (including $t$ ). A $x \%$ increase or decrease is defined to be sustained if and only if $\left|Y\left(A_{t+j}\right) / Y\left(B_{t}\right)-1\right|>|x|$ for any $j=0, \cdots, 19$. That is, if the increase or decrease with respect to the period before time $t$ is greater than $|x|$ in absolute value even as we forward the "after" period 20 times. Choosing left or right windows of 10 years ensures that the series is sufficiently smoothed and that we will not reject a true transition date because there was too much variance in the series. The comment "not in sample" means that the transition criteria were not satisfied during the sample period. Year of observation is defined as year of marriage or of first child for all series except for life expectancy, where year of observation is defined as year of death.

Source: Households and Deaths Database 


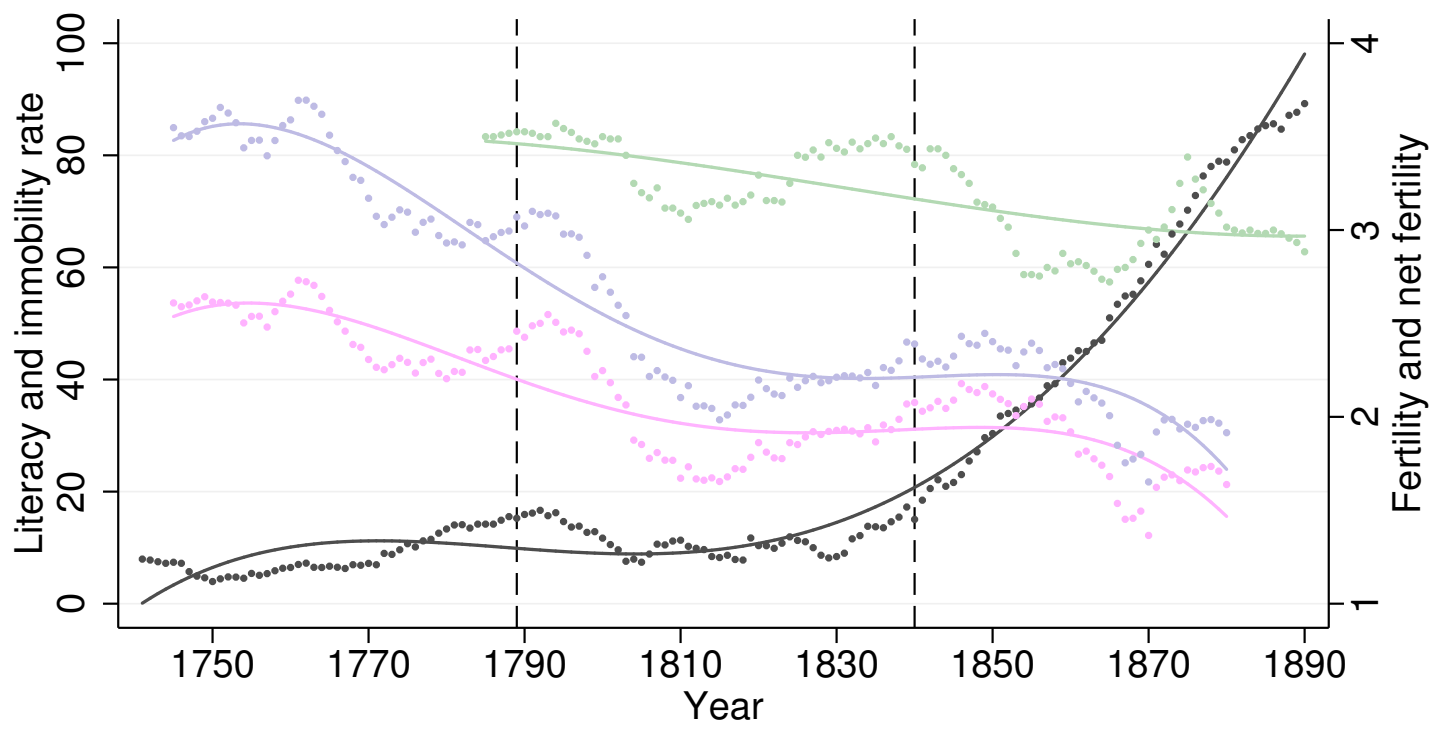

\begin{tabular}{|lll|}
\hline Literacy & - Predicted & - Rolling windows (20 years) \\
Class immobility & - Predicted & - Rolling windows (20 years) \\
Fertility & - Predicted & ・Rolling windows (20 years) \\
Net fertility & - Predicted & - Rolling windows (20 years) \\
\hline
\end{tabular}

Fractional polynomial of degree 5

Figure 7.1.0.1 - Time series plots

Note: This figure plots average literacy, class immobility, fertility and net fertility across time, computed on 20-year rolling windows. We also plot 5th degree fractional polynomial on the time series. The left axis is for the rates of mobility and literacy, while fertility and net fertility are on the right axis. We do not plot life expectancy at 20 because it it is on a different scale and it is increasing at a constant rate throughout the period.

Source: Households Database 